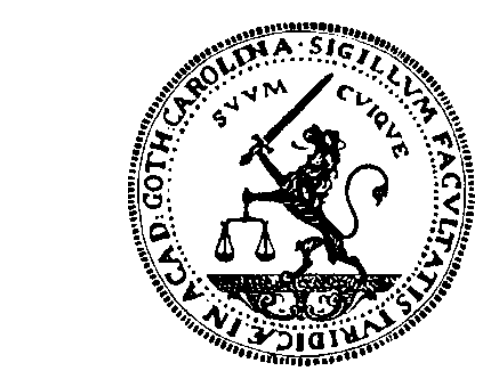

\author{
FACULTY OF LAW \\ Lund University
}

Azad Mammadli

Reflecting

\title{
Environmental Protection Requirements in the EU State Aid Policy
}

\author{
JAEM03 Master Thesis \\ European Business Law \\ 30 higher education credits \\ Supervisor: Eduardo Gill-Pedro \\ Term: Spring 2020
}




\section{CONTENTS}

ACKNOWLEDGEMENTS.

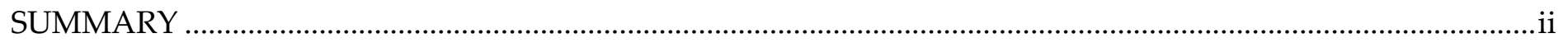

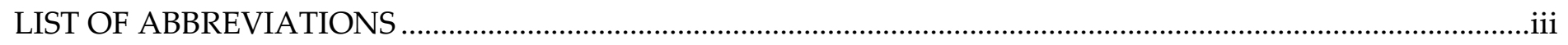

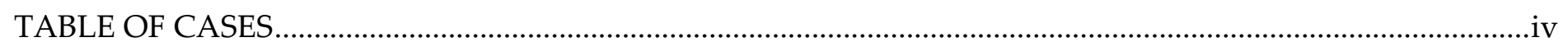

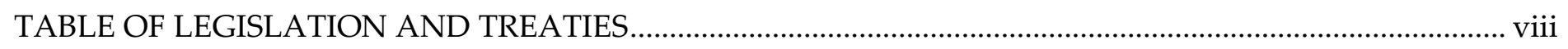

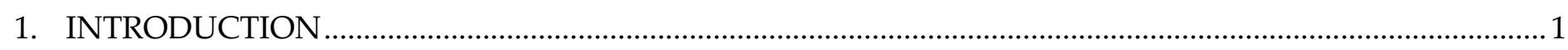

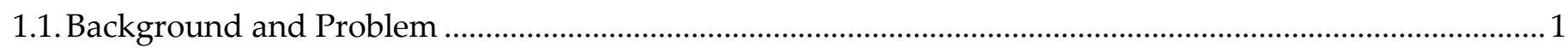

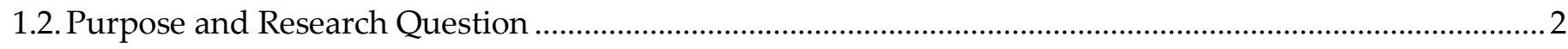

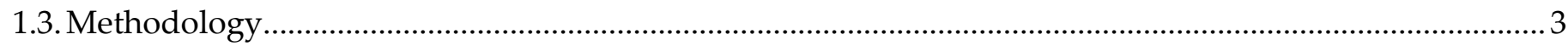

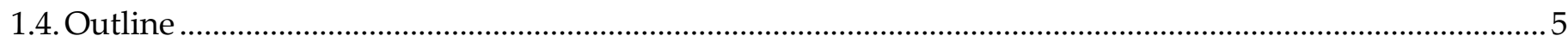

2. SETTING THE SCENE: OVERARCHING FUNDAMENTALS OF THE EU LAW IN THE CONTEXT OF

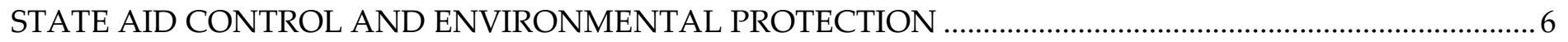

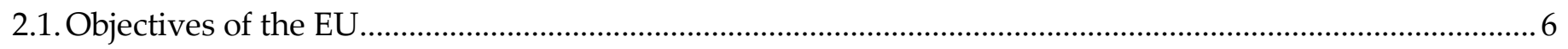

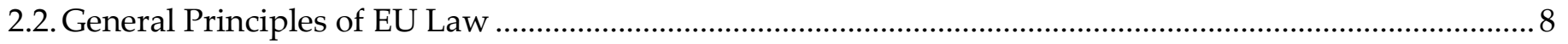

2.3. Division and Exercise of Competences between the EU and the Member States......................................9

3. EU LEGAL FRAMEWORK OF STATE AID CONTROL AND ENVIRONMENTAL PROTECTION........... 11

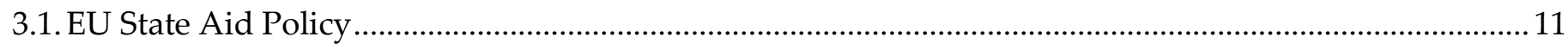

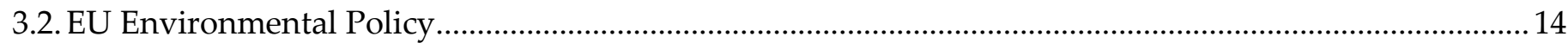

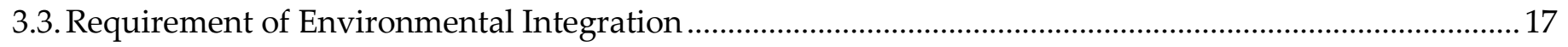

4. ENVIRONMENTAL PROTECTION AS INTEGRATED INTO THE EU STATE AID POLICY ....................20

4.1. Introduction to the EU Environmental State Aid Policy …....................................................................20

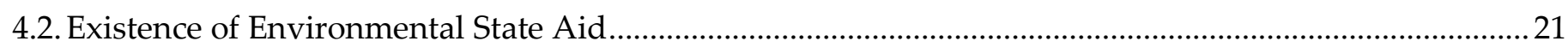

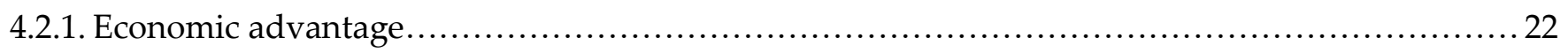

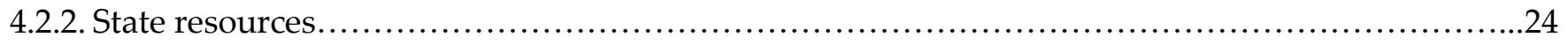

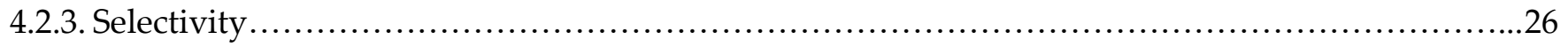

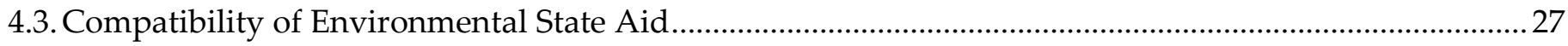

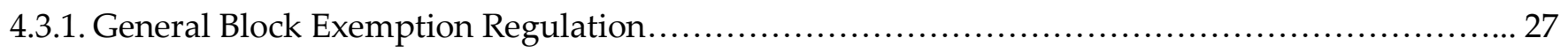

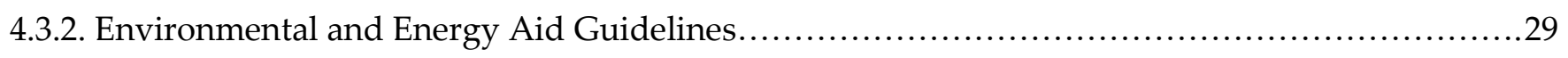

4.3.3. Environmental Protection in Certain Aid Categories........................................30

4.3.4. Compatibility Assessment under the TFEU rules........................................... 38

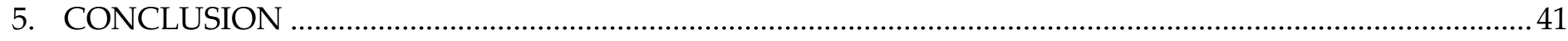

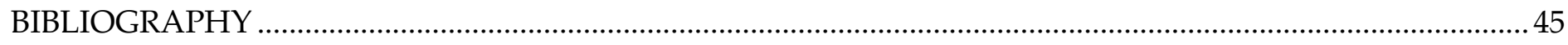




\section{ACKNOWLEDGEMENTS}

This thesis marks my final days at Lund University. And I am thankful to many.

Exactly two years ago, as I am writing these sentences, I received a scholarship offer from the University, without which this journey would be impossible. Thousand thanks to those generous people who funded the scholarship as well as the selection committee who decided that I should be one of the lucky.

I am thankful to my supervisor Eduardo Gill-Pedro not only for his guidance and constructive feedback for this thesis but also for his general academic support throughout the program.

I also have to thank my family. Hardly a day of these two years passed by without receiving support messages and prayers from Baku to Shamkir to Stockholm to Fairfax. I am especially grateful to my mother for pointing at the faculty building with her finger in a photo taken some years before my admission to the University. Cheers, mom!

This does not mean that I did not have a family in Lund. Azerbaijanis in Skåne were warm and helpful, even more than I expected. Special thanks go to Babak, Gushvar, Asena, Leyla, Seymur, Ulvi, Ruhiyya and Rustam - without you, Lund would not feel like home.

Finally, I would like to express my special gratitude to my wife Fidan, whom I sat with behind a desk not only for the past months but for the major part of the last 10 years. It has been a long journey and I cannot imagine it without you next to me. This thesis would be much harder to complete without your continuous support and encouragement. Thank you for being there whenever I felt lost, tired or broken. 


\section{SUMMARY}

European Union is one of the top-performing parts of the world in environmental matters: its Member States push hard to address modern environmental challenges they face, including climate change, and achieve their environmental targets. However, in doing so, the Member States need to comply with European Union law. The State aid policy and the 'polluter pays' principle of the environmental policy of the European Union often seem as obstacles before the Member States to implement their national environmental policies.

On the one hand, State aid control is essential to keep the economy free from distorting state interventions and maintain a high level of competition in the internal market. On the other hand, the protection of the environment is among the priority objectives of the European Union. Moreover, requirements of environmental protection must be integrated into all policy areas, including State aid. The purpose of this work is to study how the environmental protection and its requirements are integrated into the State aid policy when these two legitimate interests - a competitive economy by controlling State aid and a green economy by promoting a higher level of environmental protection - intersect.

To present the bigger picture, the study, first, visits the fundamentals, where the objectives of the European Union, general principles of the European Union law and the competence division are briefly elaborated. Next, the European Union legal framework for State aid control, environmental protection and environmental integration is shortly presented. Finally, the question of how the objective of environmental protection is reflected in the State aid policy is addressed with a deep analysis of the General Block Exemption Regulation, Environmental and Energy Aid Guidelines, and relevant Treaty rules. The thesis shows that although the Member States are confronted by the State aid policy of the European Union, this policy actually envisages quite generous rules and approach for granting necessary environmental State aid to businesses.

Keywords: State aid, environment, environmental State aid, integration, 'polluter pays' principle 


\section{LIST OF ABBREVIATIONS}

CFREU Charter of Fundamental Rights of the European Union

EEAG Environmental and Energy Aid Guidelines

GBER General Block Exemption Regulation

PPP 'polluter pays' principle 


\section{TABLE OF CASES}

\section{Judgments of the Court of Justice}

1. C-30/59 De gezamenlijke Steenkolenmijnen in Limburg v High Authority [1961] EU:C:1961:2 ... 22

2. C-26/62 Van Gend en Loos v Administratie der Belastingen [1963] EU:C:1963:1 ... 3, 4, 6

3. C-6/64 Costa v E.N.E.L. [1964] EU:C:1964:66 ... 4

4. C-6/72 Europemballage Corporation and Continental Can Company v Commission [1973] EU:C:1973:22 ... 12

5. C-173/73 Italy v Commission [1974] EU:C:1974:71 „.. 22

6. C-78/76 Steinike \& Weinlig [1977] EU:C:1977:52 „.. 26

7. C-82/77 Van Tiggele [1978] EU:C:1978:10 ... 24

8. C-61/79 Amministrazione delle finanze dello Stato v Denkavit italiana [1980] EU:C:1980:100 ... 22

9. C-240/83 Procureur de la Republique v ADBHU [1985] EU:C:1985:59 ... 8, 23

10. C-290/83 Commission v France [1985] EU:C:1985:37 ... 26

11. C-248/84 Germany v Commission [1987] EU:C:1987:437 ... 24

12. C-310/85 Deufil v Commission [1987] EU:C:1987:96 ... 39

13. C-57/86 Greece v Commission [1988] EU:C:1988:284 ... 26

14. C-62/88 Greece v Council [1990] EU:C:1990:153 ... 19

15. C-303/88 Italy v Commission [1991] EU:C:1991:136 ... 23

16. C-354/90 Federation nationale du commerce exterieur des produits alimentaires and Others v France [1991] EU:C:1991:440 ... 10

17. C-2/90 Commission v Belgium [1992] EU:C:1992:310 ... 16

18. C-387/92 Banco Exterior de España v Ayuntamiento de Valencia [1994] EU:C:1994:100 ... 22

19. C-241/94 France v Commission [1996] EU:C:1996:353 „.. 27

20. C-39/94 SFEI and Others [1996] EU:C:1996:285 ... 22

21. C-341/95 Bettati v Safety Hi-Tech [1998] EU:C:1998:353 „.. 19

22. C-293/97 R v Minister of Agriculture, Fisheries and Food, ex parte Standley and Others [1999] EU:C:1999:215 ... 16

23. C-6/99 Greenpeace France and Others [2000] EU:C:2000:148 ... 14

24. C-143/99 Adria-Wien Pipeline and Wietersdorfer \& Peggauer Zementwerke [2001] EU:C:2001:598 ... 26

25. C-379/98 PreussenElektra [2001] EU:C:2001:160 „.. 25

26. C-280/00 Altmark Trans and Regierungspräsidium Magdeburg [2003] EU:C:2003:415 ... 40

27. C-409/00 Spain v Commission [2003] EU:C:2003:92 ... 27

28. C-320/03 Commission v Austria [2005] EU:C:2005:684 „.. 19

29. C-66/02 Italy v Commission [2005] EU:C:2005:768 ... 26

30. C-94/03 Commission v Council [2006] EU:C:2006:2 ... 19

31. C-487/06 P British Aggregates v Commission [2008] EU:C:2008:757 ... 26

32. C-480/06 Commission v Germany [2009] EU:C:2009:357 ... 16

33. C-333/08 Commission v France [2010] EU:C:2010:44 „.. 15 
34. C-378/08 ERG and Others [2010] EU:C:2010:126 ... 14, 16

35. C-279/08 P Commission v Netherlands [2011] EU:C:2011:551 ... 25, 27

36. C-400/08 Commission v Spain [2011] EU:C:2011:172 „.. 15

37. C-52/09 TeliaSonera Sverige [2011] EU:C:2011:83 ... 12

38. C-262/12 Vent De Colère and Others [2013] EU:C:2013:851 ... 25

39. C-5/14 Kernkraftwerke Lippe-Ems [2015] EU:C:2015:354 ... 26

40. C-20/15 P Commission v World Duty Free Group [2016] EU:C:2016:981 ... 9

41. C-493/14 Dilly's Wellnesshotel [2016] EU:C:2016:577 ... 13, 28

\section{Judgments of the General Court}

1. T-13/99 Pfizer Animal Health v Council [2002] EU:T:2002:209 ... 15

2. T-74/00 Artegodan and Others v Commission [2002] EU:T:2002:283 ... 16

3. Joined Cases T-228/99 and T-233/99 Westdeutsche Landesbank Girozentrale v Commission [2003] EU:T:2003:57 ... 24

4. T-308/00 Salzgitter v Commission [2004] EU:T:2013:30 ... 9

5. T-229/04 Sweden v Commission [2007] EU:T:2007:217 „.. 16

6. T-375/03 Fachvereinigung Mineralfaserindustrie v [2007] EU:T:2007:293 ... 39

7. Joined Cases T-309/04, T-317/04, T-329/04 and T-336/04 TV 2/Danmark A/S and Others v Commission [2008] EU:T:2008:457 ... 9

8. T-584/08 Cantiere navale De Poli v Commission [2011] EU:T:2011:26 ... 9

9. T-210/02 British Aggregates v Commission [2012] EU:T:2006:253 ... 27

10. T-251/11 Austria v Commission [2014] EU:T:2014:1060 ... 25

\section{Opinions of the Court of Justice}

1. Opinion 1/91 Opinion delivered pursuant to the second subparagraph of Article 228 (1) of the Treaty - Draft agreement between the Community, on the one hand, and the countries of the European Free Trade Association, on the other, relating to the creation of the European Economic Area [1991] EU:C:1991:490 ... 4

2. Opinion 1/00 Opinion pursuant to Article 300(6) EC - Proposed agreement between the European Community and non-Member States on the establishment of a European Common Aviation Area [2002] EU:C:2002:231 ... 4

3. Opinion 2/13 Opinion pursuant to Article 218(11) TFEU - Draft international agreement - Accession of the European Union to the European Convention for the Protection of Human Rights and Fundamental Freedoms - Compatibility of the draft agreement with the EU and FEU Treaties [2014] EU:C:2014:2454 ... 4 


\section{Opinions of Advocate General}

1. C-72/91 Sloman Neptun v Bodo Ziesemer [1993] Opinion of AG Marco Darmon, EU:C:1992:130 ... 26

2. C-379/98 PreussenElektra [2001] Opinion of AG Jacobs, EU:C:2000:585 ... 18, 27

3. C-161/04 Austria v Parliament and Council [2006] Opinion of AG Geelhoed, EU:C:2006:66 ... 19

4. C-195/12 IBV \& Cie [2013] Opinion of AG Bot EU:C:2013:293 ... 8

\section{Decisions of the European Commission in State Aid Cases}

1. 1999/227/ECSC on aid granted by the Land of Lower Saxony (Germany) to Georgsmarienhütte GmbH [1997] ... 23

2. (C(1998) 4195) on the measure planned by Austria for the clean-up of the Kiener Deponie Bachmanning landfill [1998] ... 36

3. 1999/272/EC on the measure planned by Austria for the clean-up of the KienerDeponie Bachmanning landfill [1999] ... 25

4. (C(2001) 3739 fin) N 416/2001 - UK: Emission Trading Scheme [2001] ... 25

5. (C(2002) 1478 final) on State aid file N 863/01 - UK: Aggregates Levy [2002] ... 27

6. (C(2003) 4488 fin) State aid N 475/2003 - Ireland: Public Service Obligation in respect of new electricity generation capacity for security of supply [2003] ... 23

7. (C(2008) 2223) C 41/05 on the State aid awarded by Hungary through power purchase agreements [2008] ... 25

8. (C(2009) 695 final) N 11/2009 - France: Temporary subsidized loan scheme for companies manufacturing green products [2009] ... 39

9. (C(2009) 9972) 2010/402 on an aid measure which the Netherlands proposes to implement, granting ceramic producers exemption from an environmental tax C 5/09 (ex N 210/08) [2009] ... 35

10. (C(2010) 4146) State aid 675/2009 - Tender for Aid for New Electricity Generation Capacity (LV) [2010] ... 23

11. (C(2010) 4499) State aid No N 178/2010 - Spain: Public service compensation linked to a preferential dispatch mechanism for indigenous coal power plants [2010] ... 40

12. (C(2012) 7133 final) SA.33984 (2012/N) - UK: Green Investment Bank [2012] ... 39

13. (C(2013) 1510 final) SA.34880 (2012/N) - Denmark: Restructuring of the tax on plant protection products and simplification of the tax on biocides [2013] ... 26

14. (C(2013) 87) State aid SA.24123 (2012/C) (ex 2011/NN) implemented by the Netherlands Alleged sale of land below market price by the Municipality of Leidschendam-Voorburg [2013] ... 24

15. (C(2014) 2247 final) State aid SA.36591 (2014/NN) - Ireland: Alleged aid to waste-to-energy facility [2014] ... 23

16. (C(2014) 4939 final) State aid SA.36290 (2014/N) - UK: Northern Ireland Gas Pipeline; extension to the West and the North West [2014] ... 23 
17. (C(2014) 5080) (EU) 2015/1226 of 23 July 2014 on State aid SA.33963 (2012/C) (ex 2012/NN) implemented by France in favour of Angouleme Chamber of Commerce and Industry, SNC-Lavalin, Ryanair and Airport Marketing Services ... 22

18. (C(2014) 7142) 2015/658 on the aid measure SA.34947 (2013/C) (ex 2013/N) which the UK is planning to implement for support to the Hinkley Point C nuclear power station [2014] ... 25

19. (C(2015) 9344 final) SA.43301 (2015/N) - Sweden: Tax exemptions and tax reductions for liquid biofuels [2015] ... 26

20. (C(2016) 3124) State Aid SA.42536 - Germany: Closure of German lignite-fired power plants [2016] ... 39

21. (C(2017) 2 final) SA.45779 (2016/NN) - Malta: Delimara Gas and Power Energy Project [2017] ... 40

22. (C(2020) 585 final) SA.55977 (2019/N) - Germany: Third budget increase for scheme to support acquisition of electric buses for urban public transport [2020] ... 39 


\section{TABLE OF LEGISLATION AND TREATIES}

\section{Legislation}

1. Decision (2010/787/EU) on State aid to facilitate the closure of uncompetitive coal mines [2010] OJ L336/24 ... 22

2. Decision No 1386/2013/EU on a General Union Environment Action Programme to 2020: 'Living well, within the limits of our planet' [2013] OJ L 354/171: paras 85-89 ... 18; Annex ... 38

3. Directive 2000/60/EC establishing a framework for Community action in the field of water policy [2000] OJ $\mathrm{L} 327 / 1 \ldots 35$

4. Directive 2003/87/EC establishing a scheme for greenhouse gas emission allowance trading within the Community [2003] OJ L275/32 ... 22

5. Directive 2004/35/CE on environmental liability with regard to the prevention and remedying of environmental damage [2004] OJ L143/56 ... 16

6. Directive 2008/98/EC on waste [2008] OJ L312/3 ... 38

7. Directive $2009 / 28 / \mathrm{EC}$ on the promotion of the use of energy from renewable sources and amending and subsequently repealing Directives 2001/77/EC and 2003/30/EC [2009] OJ L140/16 ... 35

8. Directive 2010/75/EU on industrial emissions (integrated pollution prevention and control) [2010] OJ L334/17 ... 32

9. Directive 2012/27/EU on energy efficiency [2012] OJ L315/1 ... 33

10. Regulation (EU) No 1407/2013 on the application of Articles 107 and 108 of the Treaty on the Functioning of the European Union to de minimis aid [2013] OJ L352/1 ... 23

11. Regulation (EU) No 347/2013 on guidelines for trans-European energy infrastructure [2013] OJ L349/28 ... 39

12. Regulation (EU) No 651/2014 declaring certain categories of aid compatible with the internal market in application of Articles 107 and 108 of the Treaty [2014] OJ L187/1 ... 29

\section{Treaties}

1. Charter of Fundamental Rights of the European Union [2016] OJ C202/389

2. Consolidated version of the Treaty on European Union [2016] OJ C202/13

3. Consolidated version of the Treaty on the Functioning of the European Union [2016] OJ C202/47

\section{Other Documents}

1. Communication (EUCO 75/1/13 REV 1) Conclusions of the European Council [2013] ... 31

2. Explanations relating to the Charter of Fundamental Rights [2007] OJ C303/17 ... 17

3. Recommendation 75/436 regarding cost allocation and action by public authorities on environmental matters [1975] ... 37 


\section{INTRODUCTION}

\subsection{Background and Problem}

Thanks to a high level of pollutant concentration, around $90 \%$ of the urban population in Europe breathe 'harmful-to-health' air. ${ }^{1}$ European surface waters in good ecological and chemical status account to only $40 \%$ and $38 \%$ respectively. ${ }^{2}$ The conservation status of over $60 \%$ of the protected species and habitats is not favourable. ${ }^{3}$ Soil contamination affects about 250,000 sites and potentially polluting activities are believed at almost 3 million sites in Europe. ${ }^{4}$ Climate change also knocks the door as Europe's surface temperature is projected to increase faster than the global average. ${ }^{5}$

Although the European Union ('EU' or the 'Union') is one of the top-performing parts of the world in environmental matters ${ }^{6}$ with its 19 Member States in the list of top 30 countries with the highest Environmental Performance Index ${ }^{7}$ the recent stats above show some of the massive environmental challenges the European countries face nowadays, which are not the 'products' of today and root from some decades ago. Even though the Union still experiences the mentioned and other environmental problems today, environmental policy has long been, and continues to be, at the centre of attention in the EU.

Despite a whole separate policy area protecting the environment in the EU, a high level of environmental protection, the number one objective of this policy, could not be reached without cooperating with other policy areas, be it the competition, energy or foreign policies. A foundation for this cooperation had to be laid down to have the goals before the environment policy achieved. With this in mind, the Treaty of Amsterdam of 1997 established the requirement of integrating environmental protection into all EU policies as a Treaty rule. This requirement serves to ensure that when defining or implementing any of its policies, the Union institutions take due account of environmental protection requirements. All policy areas and activities that serve the establishment and functioning of the internal market project are also bound to fulfil this integration requirement. The internal market is an area of prosperity and freedom and provides the free movement of goods, services, capital, people and businesses in the Union. It also plays a role of the ideological basis for enforcing the competition and public procurement rules, consumer protection, a high level of protection and improvement of the quality of the environment, harmonisation of laws, etc. throughout the EU.

\footnotetext{
${ }^{1}$ European Environmental Agency, 'Air Pollution' (European Environmental Agency, last modified 09 October 2017)

$<$ https://www.eea.europa.eu/themes/air/intro> accessed 18 February 2020

${ }^{2}$ European Environmental Agency, European Waters: Assessment of Status and Pressures 2018 (Publications Office of the European Union 2018) 6

${ }^{3}$ European Environmental Agency, 'Biodiversity - Ecosystems' (European Environmental Agency)

$<$ https://www.eea.europa.eu/themes/biodiversity> accessed 18 February 2020

${ }^{4}$ European Environmental Agency, 'Contamination from Local Sources' (European Environmental Agency, last modified 21 November 2019) < https://www.eea.europa.eu/themes/soil/soil-threats> accessed 24 February 2020

${ }^{5}$ Jacob Daniela and others, 'EURO-CORDEX: New High-Resolution Climate Change Projections for European Impact Research' (2014)

14(2) Regional Environmental Change 563

${ }^{6}$ Adam Shirley, 'Which Are the World's Most Environmentally Friendly Countries?' (World Economic Forum, 20 May 2016)

< https://www.weforum.org/agenda/2016/05/which-are-the-worlds-most-environmentally-friendly-countries/ > accessed 5 June 2020

${ }^{7}$ Zachary Wendling and others, 2018 Environmental Performance Index (Yale Center for Environmental Law \& Policy 2018 ) 15
} 
The State aid policy of the EU is not an exception - integration of environmental protection into this EU policy is a duty before the policymakers. As a rule, aid in the form of an advantage granted by the Member States to selected businesses, which affects the intra-Union trade, is prohibited. Although aid that meets these criteria is generally prohibited, a few exceptions are in place to allow State aid in special circumstances for some legitimate goals, including environmental protection. Some aid automatically becomes compatible with the internal market, while others must be assessed to conclude whether they can be allowed to be granted.

In spite of the prohibition on State aid and the EU rule of "polluter should pay", large amounts of public resources are still involved in bearing the costs for preventing or remedying damage to the environment. For example, in the area of management of contaminated sites, 35\% of the total expenditure is still provided by public money to fund remediation activities. ${ }^{8}$ Around 53\% of total State aid provided in 2017 was granted to support the environmental protection and energy-saving measures, while an increase of EUR 4.4 billion was observed just a year after. ${ }^{9}$ What these numbers show is that it is not really always the polluter that pays, but taxpayers' hands often go into their pockets to help overcome the environmental damages or threats created by private companies.

\subsection{Purpose and Research Question}

This problem brings us to the purpose of this study. State aid is, generally, prohibited in the EU. This is also true in the environmental context. Moreover, allowing environmental aid would, to a great extent, undermine the 'polluter pays' principle - granting aid to certain undertakings through State resources ultimately means, in most cases, that the polluter does not pay.

On the one hand, State aid control is essential to keep the EU economy free from distorting state interventions and maintain a high level of competition in the internal market. On the other hand, the protection of the environment is among the priority objectives of the EU. Additionally, according to the EU law, it must be integrated into all other policy areas, including the State aid. The purpose of this work is, therefore, to study how the objective of environmental protection and its requirements are integrated into the State aid policy when these two legitimate interests of the EU - a competitive economy by controlling State aid and a green economy by promoting a higher environmental protection - intersect. The research question in this study is formulated as follows: how are the requirements of the EU objective of environmental protection taken into account and reflected in the EU's State aid policy?

To achieve the purpose of the study and answer the research question, it is necessary, first, to understand the fundamentals of EU law and general legal framework that applies to the situation. This is why, overarching fundamentals of the EU law in the context of the problem in this thesis (objectives of the EU, general principles of the Union law and division of competences between the EU and its Member States) and general legal

\footnotetext{
${ }^{8}$ European Environmental Agency (n 4)

${ }^{9}$ European Commission, 'State Aid Scoreboard 2018' (European Commission, last updated 24 January 2019)

<https://ec.europa.eu/competition/state aid/scoreboard/index en.html\#what > accessed 26 February 2020
} 
framework covering the two policy areas at hand and the integration requirement are explored. Then the legal tools and the acts of relevant EU institutions through which the environmental protection is taken into account in the State aid policy are examined to see how the said integration happens in law-making and practice.

\subsection{Methodology}

The main methodology employed in this thesis is the European legal method. The method implies that EU law matters should be analysed through teleological interpretation in the light of the primary objectives of the Union, general principles of the EU law and the specific characteristics of the EU legal order.

As Pierre Pescatore noted, the Court of Justice of the European Union ('CJEU' or the 'Court') has given priority to teleological interpretation over the others when interpreting the European Treaties, which are entirely based on the idea that the EU must achieve some objectives of paramount constitutional importance. According to the teleological interpretation, since the Treaties are generally drafted in broad terms, the Court must interpret the EU law provision in question by exercising its powers of judicial review to give that provision a concrete or narrower meaning or expression in the light of the objectives of the EU. In addition to this, the Court must take into account the objectives specified in the Treaties (which can also be attributed to the general principles of EU law) and fill the gap between the generality of primary EU law and the high degree of precision of secondary EU law. It should also be noted that a pure textualist approach is not enough to interpret the Treaty provisions in a complete and consistent way. ${ }^{10}$

When it comes to specific characteristics of the EU law, it must be noted that they have been developed mainly by the CJEU during the decades of the existence of the EU and its predecessors. EU law has direct effect before national and European courts and administrative bodies (but some EU law provisions lack direct effect), supremacy over national legal order and autonomy in interpreting and applying European law provisions through the Court. Any matter of EU law should, therefore, be explored by taking these principles into due account.

Principle of direct effect should be the starting point when talking about the characteristics of EU law. The Court has confirmed that, according to the spirit, the general scheme and the wording (or in other words teleological interpretation) of Treaties, some EU law provisions produce direct effects and create individual rights which national courts must protect. ${ }^{11}$ This means that provisions with direct effect do not need any implementing legal acts for their application; they become a source of law for national administrative bodies and courts, ${ }^{12}$ and thus, can be immediately invoked before a national or European court by individuals. By

\footnotetext{
${ }^{10}$ Koen Lenaerts and Jose Gutierrez-Fons, 'To Say What the Law of the EU Is: Methods of Interpretation and the European Court of Justice' (2014) 20(2) Columbia Journal of European Law 3, 31-35

${ }^{11}$ Case C-26/62 Van Gend en Loos v Administratie der Belastingen [1963] EU:C:1963:1, 13

${ }^{12}$ Michal Bobek, 'The Effects of EU Law in the National Legal Systems' in Catherine Barnard and Steve Peers (eds), European Union Law ( $2^{\text {nd }}$ edn, OUP 2017) 146
} 
mentioning this characteristic, the Court described the Union as "a new legal order of international law" and 'declared' "not only the Member States but also their nationals" as its subjects. ${ }^{13}$

Principle of primacy is another distinctive feature of EU law. According to this principle, in case of a conflict between the Union law and national law, EU law prevails. EU law has to be applied by national authorities in cases of conflict with national law provisions. The principle was developed by the Court, according to which, the law arising from the Treaties is "an independent source of law" and cannot be overridden by national law provisions. ${ }^{14}$ This approach by the Court was later marked as a 'legal revolution' ${ }^{15}$ as it empowered national courts to set aside, but not repeal, the provisions of national law in contradiction with EU law. ${ }^{16}$

Lastly, the principle of autonomy of the EU law should also be mentioned among its characteristics. According to the autonomy of the EU law, the Member States accept the Court's judicial monopoly in the interpretation or application of the Treaties. A potential threat to this autonomy was enough for the Court to hold that the draft agreement on the European Economic Area was incompatible with the Treaties. ${ }^{17}$ The Court examined the compatibility of agreement on European Common Aviation Area with the EU law also in the light of the principle of autonomy before finding no significant threat against it. This led the Court to hold the said draft agreement compatible with the principle and, in general, the Treaties. ${ }^{18}$ Finally, the draft agreement providing for the accession of the EU to the Convention for the Protection of Human Rights and Fundamental Freedoms was held incompatible with the EU law because it, among others, undermined the Court's autonomy by allowing for a second dispute resolution mechanism among the Member States. ${ }^{19}$ Current President of the Court sees the autonomy of the EU law governed by two dynamics: negatively, autonomy pursues to define what the EU law is not - an ordinary international law, while positively, autonomy attempts to define what the EU law is - an autonomous legal order, which means a self-sufficient system of norms and judicial monopoly over EU law matters. ${ }^{20}$

\footnotetext{
${ }^{13}$ Van Gend en Loos (n 11) 12

${ }^{14}$ Case C-6/64 Costa v E.N.E.L. [1964] EU:C:1964:66, 594

${ }^{15}$ Morten Rasmussen, 'From Costa v ENEL to the Treaties of Rome: A Brief History of a Legal Revolution', in Miguel Maduro and Loic Azoulai (eds), The Past and Future of EU Law: The Classics of EU Law Revisited on the 50 th Anniversary of the Rome Treaty (Hart 2010) 68 ${ }^{16}$ Amedeo Arena, 'From an Unpaid Electricity Bill to the Primacy of EU Law: Gian Galeazzo Stendardi and the Making of Costa v. ENEL' (2019) 30(3) European Journal of International Law 1017, 1034

${ }_{17}$ Opinion 1/91 Opinion delivered pursuant to the second subparagraph of Article 228 (1) of the Treaty - Draft agreement between the Community, on the one hand, and the countries of the European Free Trade Association, on the other, relating to the creation of the European Economic Area [1991] EU:C:1991:490, para 35

${ }_{18}$ Opinion 1/00 Opinion pursuant to Article 300(6) EC - Proposed agreement between the European Community and non-Member States on the establishment of a European Common Aviation Area [2002] EU:C:2002:231, para 26

${ }^{19}$ Opinion 2/13 Opinion pursuant to Article 218(11) TFEU - Draft international agreement - Accession of the European Union to the European Convention for the Protection of Human Rights and Fundamental Freedoms - Compatibility of the draft agreement with the EU and FEU Treaties [2014] EU:C:2014:2454, paras 194, 208, 212

${ }^{20}$ Koen Lenaerts, 'The Autonomy of European Union Law' (2018) 4 Diritto dell’Unione Europea 617, 618
} 


\subsection{Outline}

An outline of the study should be given at the outset to let the reader have an overview of its general structure. This thesis comprises four chapters. Chapter 1, which the reader is reading right now, is an introduction to the thesis and presents the background and purpose of the study, the existing problem, the research question and the methodology employed.

Chapter 2 provides certain fundamentals of the EU law, in the light of which the thesis problem is investigated in this study. Here, first, a short overview of the objectives of the EU is given because the thesis problem is a scene for a potential clash between two such objectives. Then, the general principles of the EU law are visited in the context of the problem. In the end, a brief analysis of the division of competence between the EU and the Member States is provided to have a clear understanding of who has the authority to act in relation to the problem.

Chapter 3 introduces the basic legal framework covering the thesis problem. Here the general view of the internal market, environment and State aid policies of the EU is given before the analysis of obligation of the environmental protection integration.

Chapter 4 examines the legal tools through which the environmental considerations are taken into account and reflected in State aid rules and decisions. The Chapter mainly focuses on relevant Treaty provisions, as well as secondary and soft law instruments. The practice of the relevant EU institutions is also covered throughout the Chapter.

Chapter 5 is a conclusion to the study. It briefly re-presents the findings in the previous chapters and comments on the current situation regarding environmental protection considerations in the EU State aid policy. 


\section{SETTING THE SCENE: \\ OVERARCHING FUNDAMENTALS OF THE EU LAW IN THE CONTEXT OF STATE AID CONTROL AND ENVIRONMENTAL PROTECTION}

The purpose of this thesis, as noted in the first chapter, is to study how environmental protection and its requirements are integrated into the State aid policy. The EU's State aid and environment policies, the requirement of environmental integration and the tools and decisions through which environmental considerations are reflected in State aid rules are important to explore for this purpose. But to see the bigger picture, even more indispensable is to examine this issue with respect to the overarching fundamentals of EU law. First, the objectives of the Union, which must be complied by all Union policies and activities, including the policy of State aid, are briefly studied. Next, the focus turns to the general principles of EU law in the context of the EU State aid and environment policies. Lastly, the division of power in the Union is shortly described in relation to State aid and environmental matters.

\subsection{Objectives of the EU}

EU law provisions are interpreted and applied in light of the objectives of the EU. This allows the Union to march in the direction of reaching its ultimate objectives as well as to shape its legal order in a systematic way that is consistent with those foremost aims. The relevance of a quick study of the EU objectives in this thesis is that the EU law provisions on environmental protection and State aid control are also interpreted and weighed up in the light of these objectives. The problem in this study is examined in the light of two objectives of the Union - the internal market and a high level of environmental protection. It should be noted that when a particular EU law provision pursues two or more objectives with equal importance, the principle of proportionality is applied by the Court to decide the most 'privileged' objective. ${ }^{21}$

The objectives of the EU are specified in Article 3 of the Treaty on European Union²2 ('TEU'). The Article indicates promoting peace, EU values and the well-being of the Member States' peoples as the aim of the Union. However, establishing an internal market remains as the most emblematic project and an inherent objective of the EU. One could say that even other objectives of the EU enshrined in Article 3 TEU as well as the policies and activities it practices are pursued with the very aim of achieving the internal market objective of the Union. The Court, in the early years of the then-European Economic Community, has also recognised establishing the internal market as the objective of the Treaties. ${ }^{23}$

The internal market is designed to increase economic wealth and economies of scale, and to improve the efficiency of the allocation of resources by allowing the factors of production to freely move to the areas where they are most valued. It is also the driving force of the European economic integration, as previously separate

\footnotetext{
${ }^{21}$ Lenaerts and Gutierrez-Fons (n 10) 33

${ }^{22}$ Consolidated version of the Treaty on European Union [2016] OJ C202/13

${ }^{23}$ Van Gend en Loos (n 11) 12
} 
economies of the Member States become integrated within a single EU-wide economy. The EU hosts various forms of economic integration: the free trade area - an arrangement where all customs duties and quotas on trade are removed, customs union - an agreement upon which a common level of tariff on goods entering to the Union is applied, common market - a platform that ensures the free movement of all factors of production, and a (partial) economic union - a common market with a unified monetary and fiscal policy. ${ }^{24}$ This economic integration is attained either by prohibition by the EU on adoption and application of national legal provisions that hinder cross-border trade and free movement of persons - negative integration, or by harmonisation of diverse national laws through a Union measure - positive integration. The latter, in turn, can also take the form of either minimum harmonisation (setting minimum standards which do not preclude the Member States from having higher standards) or maximum harmonisation (an exhaustive regulation of a particular area at the EU level).

The objective of establishing the internal market is restated in Article 26 of the Treaty on the Functioning of the European Union ${ }^{25}$ ('TFEU'), where the internal market is described as an area without internal frontiers where the free movement of goods, persons, services and capital is ensured under the provisions of the EU Treaties. The article also ensures balanced progress in all sectors of the internal market concerned. The absence of a deadline in this Article, unlike some previous Treaties, shows that the internal market is an ongoing project rather than one that could be 'completed' by a set date. ${ }^{26}$ Since creating the internal market is an area of shared competence under Article 4(2)(a) TFEU, the objective (and obligation) in Article 26 TFEU is a source for possible legal effects and consequences both for the EU and the Member States. ${ }^{27}$

The concept of the internal market has been broadened by the EU institutions, including the Court, to encompass not only the economic integration but also social rights, labour policy and the environment in the EU. ${ }^{28}$ A successful single market required widespread harmonisation of standards of consumer and environmental protection. ${ }^{29}$ This re-conceptualisation of the internal market to cover not only purely economic phenomena, such as the customs union, and free movement of goods and other factors of production, but also, among others, protecting the environment and consumer safety perfectly sums up why establishing an internal market is a living objective of the EU and why competition and environmental concerns should be examined in light of this overarching objective. Pursuant to Article 114(3) TFEU, the European Commission (the 'Commission') is also expected to take as a base a high level of protection in its legislative proposals concerning health, safety, environmental protection and consumer protection where those proposals have as their object the establishment and functioning of the internal market.

Another relevant objective of the EU is achieving a high level of protection and improvement of the quality of the environment. Together with Article 191 TFEU (policy on the environment), the mention in Article

\footnotetext{
${ }^{24}$ Dennis Swann, The Economics of the Common Market (7th edn, Penguin 1992) 11-12

${ }^{25}$ Consolidated version of the Treaty on the Functioning of the European Union [2016] OJ C202/47

${ }^{26}$ Paul Craig and Grainne de Burca, EU Law: Text, Cases, and Materials (5 ${ }^{\text {th }}$ edn, OUP 2011) 588

${ }^{27}$ ibid 589

${ }^{28}$ Paul Craig, 'The Evolution of the Single Market' in Catherine Barnard and Joanne Scott (eds), The Law of the Single European Market: Unpacking the Premises (Hart 2002) 38

${ }^{29}$ Joseph Weiler, 'The Transformation of Europe', (1991) 100(8) The Yale Law Journal 2403, 2478
} 
3(3) TEU raises the high level of environmental protection to the status of a Union target. ${ }^{30}$ This is why the high level of environmental protection is seen as the raison d'être of the EU environment policy and the principles of prevention, precaution and 'polluter pays' as its foundations. ${ }^{31}$ This explicit objective of reaching the highest possible standard of the protection of the environment and actively improving its quality makes the Union even more ambitious in comparison to other frameworks of environmental policy around the world..$^{32}$ The Court has also given environmental protection a particular value by defining it as one of the Union's essential objectives. ${ }^{33}$

The environmental objective in Article 3(3) TEU entails both reactive ("protection") and proactive ("improvement") approaches to environmental policy - the institutions should not only avoid degradation of the environment but also adopt a more interventionist stance and seek to improve its quality. ${ }^{34}$ This is often done through positive harmonisation of national laws regulating the production, provision and free movement of goods and services that impair the environment.

\subsection{General Principles of EU Law}

General principles of EU law unify the law, fill the gaps, and provide for weight and legitimacy to the EU legal order as a whole. These principles play such an important role because, among others, the Treaties tend to lay down very limited and open frameworks, which were essentially focused on economic integration rather than legal issues such as fundamental rights. As a result, the Court often takes the stage to fill in these general frameworks, provide protection and give life to the general spirit of the Treaties. ${ }^{35}$ These principles are common to EU law, carry additional weight and refer to a core value of the Union law. ${ }^{36}$

Fundamental rights are recognised as general principles of the EU law in Article 6(3) TEU. According to this provision, they originate either from Convention for the Protection of Human Rights and Fundamental Freedoms or constitutional traditions of Member States. After decades of a rather 'chaotic' establishment by the Court in its case law, these fundamental rights were incorporated into a single and Treaty-equivalent document - the Charter of Fundamental Rights of the European Union ${ }^{37}$ ('CFREU' or the Charter). Article 37 CFREU (Environmental Protection) combines the purposes of Article 3(3) TEU and Articles 11 and 191 TFEU, 38 by restating, first, attaining a high level of environmental protection as an objective of the Union and, second, the obligation of integration of the environmental protection requirements into all other policy areas and activities of the EU. State aid rules should also respect, and comply with, fundamental rights recognised under the EU

\footnotetext{
${ }^{30}$ Case C-195/12 IBV E Cie [2013] Opinion of AG Bot EU:C:2013:293, para 82

${ }^{31}$ Delphine Misonne, 'The Importance of Setting a Target: The EU Ambition of a High Level of Protection' (2015) 4(1) Transnational Environmental Law 11, 30

32 ibid 11

${ }^{33}$ Case C-240/83 Procureur de la République v ADBHU [1985] EU:C:1985:59, para 13

${ }^{34}$ Nicolas de Sadeleer, EU Environmental Law and the Internal Market (OUP 2014) 36 and 45

${ }^{35}$ Armin Cuyvers, 'General Principles of EU Law' in Emmanuel Ugirashebuja and others (eds), East African Community Law: Institutional, Substantive and Comparative EU Aspects (Brill 2017) 217-219

36 Takis Tridimas, The General Principles of EU Law (2 $2^{\text {nd }}$ edn, OUP 2006) 1

${ }^{37}$ Charter of Fundamental Rights of the European Union [2016] OJ C202/389

${ }^{38}$ Explanations relating to the Charter of Fundamental Rights [2007] OJ C303/17, explanation on art 37
} 
Treaties. Frequently applied fundamental rights and freedoms in State aid cases include the right to a fair trial, the right of defence ${ }^{39}$ and the right to good administration. ${ }^{40}$

The principle of equal treatment or non-discrimination establishes, in essence, that those subject to EU law have the right to receive the same treatment and not to be discriminated against based on certain criteria. State aid for undertakings is prohibited if it distorts or threatens to distort competition by favouring certain undertakings or the production of certain goods, which is commonly referred to as the selectivity criterion in State aid control. The need to assess the selectivity of aid symbolise the State aid prohibition as a specific nondiscrimination standard..$^{41}$ The Court sees discrimination against undertakings as a prerequisite of the existence of aid. ${ }^{42}$ Like in the State aid policy, the principle of equal treatment is also respected in definition and implementation of the EU environmental policy as well as its judicial review by the Court. ${ }^{43}$

Another vital general principle of EU law is the principle of legal certainty, along with the principle of protection of legitimate expectations. A basic understanding of the principle is that everyone has the right to expect that their rights will not be violated without a valid reason. ${ }^{44}$ The EU Treaties does not define these principles, but a similar understanding of the principle of protection of legitimate expectations has been developed by the Court mainly based on the laws of the Member States, ${ }^{45}$ which has expressed its views on the principles only rarely. ${ }^{46}$

\subsection{Division and Exercise of Competences between the EU and the Member States}

The two different goals of the EU - controlling State aid and promoting a high level of environmental protection - may give rise to clashes of interests at Union level. This brings the question of competence in the EU: who has the authority to act in cases of such clashes?

The Member States are independent sovereign states, but by joining the EU, they have agreed to forgo some parts of their sovereignty and delegate certain decision-making powers to the Union, which equips the EU with legislative and policy-making competences. The limits of the EU's competences are guided by the principle of conferral, as determined in Article 5(1) TEU. According to Articles 3(6), 4(1) and 5(2) TEU, under the principle of conferral, the EU may only act within the limits of the competences conferred upon it in the Treaties by the Member States, while competences not conferred upon the EU in the Treaties remain with the Member States.

\footnotetext{
${ }^{39}$ Joined Cases T-309/04, T-317/04, T-329/04 and T-336/04 TV 2/Danmark A/S and Others v Commission [2008] EU:T:2008:457, paras 136-146 ${ }^{40}$ Case T-584/08 Cantiere navale De Poli v Commission [2011] EU:T:2011:26, paras 89-90

${ }^{41}$ Joachim Englisch, 'Equality under State Aid Rules and VAT' (2019) 8 World Journal of VAT/GST Law 17, 24

${ }^{42}$ Case C-20/15 P Commission v World Duty Free Group [2016] EU:C:2016:981, para 86

${ }^{43}$ David Langlet and Said Mahmoudi, EU Environmental Law and Policy (OUP 2016) 63

${ }^{44}$ Marek Rzotkiewicz, 'The General Principles of EU Law and Their Role in the Review of State Aid Put into Effect by Member States', (2013) 3 European State Aid Law Quarterly 464, 470

45 Tridimas (n 36) 4

${ }^{46}$ See, eg, Case T-308/00 Salzgitter v Commission [2004] EU:T:2013:30, paras 157-183
} 
Division of competences between the EU and its Member States is clarified through three main categories of competences. The EU has exclusive competences through which it alone can develop policies, legislate and adopt binding acts in certain areas. Establishing competition rules necessary for the functioning of the internal market, which includes State aid rules also, is one of such areas according to Article 3(1)(b) TFEU. Besides, Article 108 TFEU recognises the exclusive competence of the Commission in assessing the compatibility of State aid with the internal market, subject only to the Court supervision. ${ }^{47}$ Apart from the compatibility assessment, the Commission has the authority to keep the Member States' practices under review and order them to abolish or readjust activities under Article 108(1)-(3) TFEU.

The EU and the Member States share competences in several areas set out in Article 4(2)(e) TFEU, including the internal market. While the control over State aid lies exclusively with the Commission, the area of environment hosts shared competences between the EU and the Member States. In the area of State aid granted for environmental protection, this is a potential source for clashes of interests pursued, on one hand, by the EU to keep the competition undistorted and, on the other, by the Member States to address their environmental concerns.

The exercise of the Union competences, on the other hand, is governed through the principles of subsidiarity and proportionality. According to Article 5(3) TEU, under the principle of subsidiarity in the areas of non-exclusive competences, the EU may act only if, and in so far as, the objective of an action cannot be sufficiently achieved by the Member States, but could be better attained at the Union level. Although the EU enjoys exclusive competence to establish competition rules necessary for the functioning of the internal market, the overall framework is intended to reflect the principle of subsidiarity. ${ }^{48}$ Under the principle of proportionality of Article 5(4) TEU, the content and scope of EU action may not go beyond what is necessary to achieve the objectives of the Treaties. Both principles are applied as laid down in Protocol No. 2 on the application of the principles of subsidiarity and proportionality.

As State aid and environmental policies of the EU are the areas governed by different categories of competences, this division of competences must be taken into due account in definition, implementation and judicial review of those policy areas and relevant legal provisions.

\footnotetext{
${ }^{47}$ Case C-354/90 Fédération nationale du commerce extérieur des produits alimentaires and Others v France [1991] EU:C:1991:440, para 14

${ }^{48}$ European Union Committee, Brexit: Competition and State Aid (HL 2017-19, 67) para 10
} 


\section{EU LEGAL FRAMEWORK OF STATE AID CONTROL AND ENVIRONMENTAL PROTECTION}

After having a look at the overarching fundamentals of the EU law, the basic legal framework should be covered to proceed to the main research question of this thesis work. The visited legal framework includes the State aid and environment policies of the Union as well as the obligation of integrating environmental protection requirements into the EU policies and activities. First, the State aid policy of the EU is studied, which is one of the three pillars of the Union's competition policy, along with antitrust and merger policies. Next, the environmental policy of the EU is analysed. Lastly, the environmental integration requirement is explored.

\subsection{EU State Aid Policy}

EU competition law is among the leading frameworks through which the objective of establishing an internal market in the EU is realised. It is not accidental that competition was once even seen as the raison d'être of the European integration. ${ }^{49}$ Article 3(3) TEU indicates several qualities of the internal market, one of which is a highly competitive social market economy. The high competition referred to in this article is an implication of creating the internal market.

Besides keeping competition at a high level, maintaining it undistorted is also a means to achieve the internal market objective. The 50-years-old commitment to the undistorted competition - last seen in Article $3(1)(\mathrm{g})$ of Treaty establishing the European Community - was, however, repealed with the adoption of the Lisbon Treaty. But this omission of the said means from the main body of the Treaties did not mean much as Protocol No. 27 on the internal market and competition, which is annexed to, and enjoys the same legal value as, the Treaties according to Article 51 TEU, is now "ensuring that competition is not distorted" in the EU. Competition policy, with State aid control as its integral part, is taken as a tool for achieving the internal market in this thesis because it is not an end in itself, but the best means to create the conditions for growth - integrating competition into the very concept of the internal market in Protocol No. 27 proves that they simply cannot exist without each other..$^{50} \mathrm{At}$ the same time, some scholars see the reassertion of the intimate link between the internal market and protection of undistorted competition in the Protocol indicating that the latter remains a fundamental objective of the Union. ${ }^{51}$ The Protocol thereby goes far beyond merely ensuring the Union's legislative powers in the field of competition and guarantees that the current legal situation remains

\footnotetext{
${ }^{49}$ David Gerber, 'The Future of Article 82: Dissecting the Conflict' in Claus-Dieter Ehlermann and Mel Marquis (eds), European Competition Law Annual 2007: A Reformed Approach to Article 82 EC (Hart 2008) 44

${ }^{50}$ Neelie Kroes, 'Competition Policy: Achievements in 2006; Work Programme in 2007; Priorities for 2008' (2007) European Parliament Economic and Monetary Affairs Committee, Speech/07/425 (26 June 2007) 2

${ }^{51}$ Francesco Costamagna, 'The Internal Market and the Welfare State: Anything New after Lisbon?' in Martin Trybus and Luca Rubini (eds), The Treaty of Lisbon and the Future of European Law and Policy (Edward Elgar 2012) 386
} 
unchanged.52 The Court has, in several judgments, reaffirmed the importance of free and undistorted competition and the legal force of the Protocol. ${ }^{53}$

State aid control, in turn, plays the role of an important instrument for pursuing a high level of competition in the EU. One difference between the State aid rules and other competition provisions is that the former is addressed to, and regulates the conduct of, public bodies rather than private companies. This results with a serious political aspect of the EU action since the State aid policy is more likely to affect national sovereignty and interests than other fields of competition policy of the Union. ${ }^{54}$ It should also be noted that, unlike other areas of EU competition law, proofs of consumer harm and a material distortion of competition are not required in State aid control for prohibiting a particular aid measure.

Treaty rules on State aid are set out under the chapter on competition rules of Title VII Common rules on competition, taxation and approximation of laws. Article 107(1) TFEU states:

Save as otherwise provided in the Treaties, any aid granted by a Member State or through State resources in any form whatsoever which distorts or threatens to distort competition by favouring certain undertakings or the production of certain goods shall, in so far as it affects trade between Member States, be incompatible with the internal market.

To fall within the scope of this provision, the beneficiary of aid must be an undertaking. If the recipient found to be an undertaking, four elements of State aid must be present to define the measure in question as State aid in the sense of Article 107(1) TFEU. A support measure falls within the scope of this provision if it (i) confers an economic advantage that the beneficiary would not have received, at all or easily, under normal conditions; (ii) comes directly or indirectly through State resources and is imputable to the State; (iii) favours certain undertakings or a group of undertakings; and (iv) distorts or threatens to distort competition and affects intraUnion trade.

The remaining part of Article 107 TFEU sets out the derogations from the general prohibition of State aid in the EU: while State aid is in principle prohibited under Article 107(1) TFEU, Article 107(2) and (3) TFEU 'exemptions' recognise that markets may not always work properly when left completely alone and may need State intervention to work more effectively and smoothly. ${ }^{55}$ The effect of the second and third paragraphs of the Article is that a measure can still be compatible with the internal market even if it is found to be State aid. The exemptions in Article 107(2) TFEU are mandatory - if the aid falls within one of the categories specified therein, which include social aid to individual consumers, disaster aid and aid compensating for the cold war division of Germany, the Commission is required to approve it and has no discretion to decide otherwise. The larger part of cases, however, are assessed under Article 107(3) TFEU, where the Commission enjoys quite a wide discretion. Exemptions in Article 107(3) TFEU contain aid for regional economic development, an important project of

\footnotetext{
52 Josef Drexl, 'Competition Law as Part of the European Constitution' in Jurgen Bast and Armin von Bogdandy (eds), Principles of European Constitutional Law (2 ${ }^{\text {nd }}$ edn, Hart 2009) 663

53 See, eg, Case C-6/72 Europemballage Corporation and Continental Can Company v Commission [1973] EU:C:1973:22, paras 23-24; Case C52/09 TeliaSonera Sverige [2011] EU:C:2011:83, para 20

${ }^{54}$ Kelyn Bacon, European Union Law of State Aid (3 ${ }^{\text {rd }}$ edn, OUP 2017) 5

55 Suzanne Kingston, Greening EU Competition Law and Policy (CUP 2011) 379
} 
common European interest or a serious disturbance in the economy, development of certain economic activities or areas and culture and heritage conservation. The common overarching principle in Article 107(3) TFEU exemptions is that aid measures falling under this provision should help achieve an objective of common interest. ${ }^{56}$ In addition, aid to undertakings which provide services of general economic interest is assessed under Article 106(2) TFEU and the Altmark criteria. ${ }^{57}$

Article 108 TFEU specifies the procedural matters of State aid control. It is the Commission who, under the Article, has the competence to conduct the State aid control in the EU. Pursuant to Article 108(1) TFEU, the Commission reviews all systems of aid granted to undertakings by the Member States and when appropriate, proposes measures required by the progressive development or by the functioning of the internal market. Where necessary, Member States must inform the Commission of their plans to grant State aid per Article 108(3) TFEU. This provision also hosts the 'standstill obligation', according to which, Member States cannot put the proposed measures into effect until the State aid control procedure, which is described in Article 108(2) TFEU, has resulted in a final decision.

Article 109 TFEU authorises the Council of the European Union, on a proposal from the Commission and after consulting the European Parliament, to make appropriate regulations for the application of Articles 107 and 108 TFEU and determine the categories of aid exempted from the notification procedure. The Council of the EU has adopted the so-called Enabling Regulation ${ }^{58}$ on that basis, which, in turn, empowered the Commission to adopt certain exemption regulations.

Secondary law provisions also play a vital role in the definition and implementation of the State aid policy of the Union. Several block exemption regulations that were initially adopted by the Commission to cover separate types of horizontal aid were consolidated into a single regulation in 2008, which was in turn replaced by the current General Block Exemption Regulation in 2014, due to expire at the end of this year - on 31 December 2020. The current Regulation extends previous one's coverage of regional and horizontal aid to several specific types of sectoral aid and exempts further categories of horizontal aid. The basic effect of the Regulation is to exempt aid granted to undertakings by the Member States from the notification obligation of Article 108(3) TFEU if it fulfils the common provisions and conditions of monitoring, and satisfies the specific conditions set for the relevant categories of aid, with both sets of conditions subject to strict interpretation. ${ }^{59}$ Section 7 on aid for environmental protection is among the main focuses of the next chapter. Block exemption and de minimis regulations, as well as the Commission's State aid decisions, whether as a legislative or non-legislative act, are directly applicable in the Member States according to Articles 288 and 289 TFEU, are binding on the Commission and can be relied on by Member States' authorities in granting aid.

\footnotetext{
56 See, eg, Commission, 'State Aid Action Plan - Less and Better Targeted State Aid: A Roadmap for State Aid Reform 2005-2009' (Consultation document) COM(2005) 107 final, para 10

57 See Section 4.3.4.

${ }^{58}$ Council Regulation (EC) No 994/98 of 7 May 1998 on the application of Articles 92 and 93 (now 87 and 88 respectively) of the Treaty establishing the European Community to certain categories of horizontal State aid [1998] OJ L142/1 (repealed and replaced by Council Regulation (EU) 2015/1588 of 13 July 2015 on the application of Articles 107 and 108 of the Treaty on the Functioning of the European Union to certain categories of horizontal State aid [2015] OJ L248/1)

${ }^{59}$ Case C-493/14 Dilly's Wellnesshotel [2016] EU:C:2016:577, para 37
} 
When it comes to the soft law documents, although they lack a binding force, these instruments can, with their potential impact in practice, produce legal effects. The Commission has adopted a number of notices, communications and recommendations to systematise and make its approach towards State aid matters publicly known and contribute to a high level of legal certainty among businesses and professionals. Environmental and Energy Aid Guidelines, one of the main spotlights of the next chapter, are among the prominent soft instruments. These instruments demonstrate the Commission's position in State aid-related issues, 'codify' the Commission's and the Court's past practice and establish horizontal or sector-specific rules.

\subsection{EU Environmental Policy}

The basis of the legal framework of the EU environmental policy is Title XX (Articles 191-193) TFEU, Environment. Article 191(1) TFEU lays down the objectives of EU environmental policy. These objectives include (i) preserving, protecting and improving the quality of the environment, (ii) protecting human health, (iii) prudent and rational utilisation of natural resources and (iv) promoting measures at the international level to deal with regional or worldwide environmental problems, and in particular combating climate change. This extremely general and fluid formulation of the objectives leaves the EU institutions a genuine discretionary power in the law-making process - their general wording permits a high degree of flexibility and adaptability in the aims pursued by the EU legislature. ${ }^{60}$ Lack of the definition of the notion of 'environment' in the Treaties or the fact that it is an 'all-embracing concept' ${ }^{\prime} 1$ further extends this flexibility. In addition to obvious conservation and protection goals, the Union's environmental policy also covers indirect protective measures such as liability for environmental damage, environmental penal sanctions, and access to environmental information. However, these objectives do not show a full picture of all environmental objectives pursued through the environmental policy of the Union - they must be read along with other primary law provisions. ${ }^{62}$

Article 191(2) TFEU, on the other hand, specifies the principles which the environmental policy of the Union is based on. The policy rests on the principles of precaution, prevention, proximity and the 'polluter pays' principle. Like the objectives laid down in Article 191(1) TFEU, the mentioned environmental principles also lack a precise definition, although the EU institutions have attempted to clarify the conditions under which they apply. Article 191(2) TFEU principles play a role in the interpretation of not only environmental policy acts, but also acts of other policy areas with a different legal basis, for example, internal market and Article 114 TFEU63. However, it can be assumed that these principles have no direct effect, cannot be relied upon in reviewing Member State actions if they have not been indicated in secondary law ${ }^{64}$ and thus, cannot be the basis for a decision in individual cases. ${ }^{65}$

\footnotetext{
${ }^{60}$ Saadler, EU Environmental Law and the Internal Market (n 34) 34

${ }^{61}$ Ludwig Kramer, EC Environmental Law (6 $6^{\text {th }}$ edn, Sweet \& Maxwell 2007) 2

${ }^{62}$ Edwin Alblas, 'Conflicting Goals and Mixed Rationales: A Closer Look the Objectives of EU Environmental Law in Light of the Anthropocene' (2018) 27(2) Review of European Comparative \& International Environmental Law 141, 144

${ }^{63}$ Case C-6/99 Greenpeace France and Others [2000] EU:C:2000:148

${ }^{64}$ Case C-378/08 ERG and Others [2010] EU:C:2010:126, para 46

${ }^{65}$ Kramer (n 61) 6
} 
The precautionary principle is a risk management instrument that is invoked when there is scientific uncertainty, suspicion or risks about human health or environment. The traditional approach to environmental problems such as taking measures to prevent, reduce or control proven harm to the environment has changed since the precautionary principle was added to the list of Union environmental principles. ${ }^{66}$ The Commission has published non-binding Communication on the precautionary principle where it presents its approach in applying the principle and clarifies certain misunderstandings in this area. Measures adopted under this principle must be proportionate and non-discriminatory and must be reviewed as soon as relevant scientific information is available. ${ }^{67}$ It should be noted that for the application of the precautionary principle the environmental risk must not be fully demonstrated. However, this does not imply that the application of the principle can be founded purely on hypothetical risks that lack a scientific basis. ${ }^{68}$ The correct application of precautionary principle requires, first, identification of the potentially negative consequences and, second, a comprehensive assessment of the risk based on the most reliable scientific data available and the most recent results of international research. ${ }^{6}$

According to the principle of prevention, environmental damage must be anticipated ${ }^{70}$ and prevented before its occurrence. In other words, prevention of environmental damage must be preferred to the restitution of it: on the one hand, repairing damage to the environment is often impossible and on the other, even if it is possible, the costs of prevention are usually much lower than the costs of repair. ${ }^{11}$ As the principle of precaution, the preventive principle is subject to two thresholds: the relationship between the probability and extent of damage, and a cost-benefit analysis. ${ }^{72}$ Several EU legal acts explicitly refer to the principle. Besides, the Union employs emission limits, licensing requirements and economic tools as instruments of this principle, the objective of which is to bring economic development and the desire to prevent environmental problems together. ${ }^{73}$ Rules on environmental audit and environmental impact assessment have also developed on the principle of prevention.

The principle that environmental damage should be rectified at source (also known as the proximity principle) is a principle closely linked to the principle of prevention: it becomes involved when the damage is identified but the application of the latter principle fails. ${ }^{74}$ The main aim of this principle is to deal with environmentally harmful effects as soon as possible and before their spread. The principle is primarily applied in connection with waste management in practice. In this field, this principle entails that to limit the transportation of waste as much as possible appropriate steps must be taken to ensure that waste is disposed of

\footnotetext{
${ }^{66}$ Langlet and Mahmoudi (n 43) 51

${ }^{67}$ Commission, 'Communication on the precautionary principle' COM(2000) 1 final, 3

${ }^{68}$ Case T-13/99 Pfizer Animal Health v Council [2002] EU:T:2002:209, para 146

${ }^{69}$ Case C-333/08 Commission v France [2010] EU:C:2010:44, para 92

${ }^{70}$ Saadler, EU Environmental Law and the Internal Market (n 34) 66

${ }^{71}$ Case C-400/08 Commission v Spain [2011] EU:C:2011:172, para 92

${ }^{72}$ Nicolas de Sadeleer, Environmental Principles: From Political Slogans to Legal Rules (OUP 2002) 80-82

${ }^{73}$ Langlet and Mahmoudi (n 43) 53

${ }^{74}$ Geert van Calster and Leonie Reins, EU Environmental Law (Edward Elgar 2017) 35
} 
as close as possible to the place where it is produced. ${ }^{75}$ The principle has been interpreted by the Court as requiring the waste disposal to be carried out in the nearest waste disposal installation. ${ }^{76}$

According to the 'polluter pays' principle ('PPP'), pollution costs should be incurred by the polluter and not by taxpayers or the wider society. Operators of certain activities have to take preventive measures in case of a threat to the environment and if damage has already occurred, those operators are obliged, pursuant to the principle, to take appropriate steps to remedy it urgently and pay for the costs. The principle has largely been ignored in practice, while both the EU and the Member States have spent funds to ensure compliance with environmental requirements. ${ }^{77}$ The principle becomes more important before the Court when the pieces of secondary law include explicit rules that require a certain category of persons responsible for pollution to bear the costs. ${ }^{78}$ Environmental Liability Directive, ${ }^{79}$ which implements the principle as a piece of EU legislation, lays down the requirements for effective application of the principle. The Directive covers the conditions of preventive and remedial actions and costs, the cost allocation in cases of multiple party causation and the limitation period for recovery of costs, among others. Although operators cannot be made to bear the costs of pollution which they have not caused, ${ }^{80}$ the Directive allows the presumption that if the operator's installations are located close to the polluted area, then there is a relation between the operator and the pollution..$^{81}$

According to Article 191(3) TFEU, in preparing its policy on the environment, the EU must take account of certain criteria, which comprise scientific and technical data, environmental conditions in the various regions of EU, benefits and costs of action or lack of action, the economic and social development of the Union and its regions. The EU and the Member States share competences to cooperate with third countries and international organisations in the area of the environment under Article 191(4) TFEU.

In general, the objectives, principles and criteria which the Union legislature must respect in implementing the environmental policy set in Article 191 TFEU have legal effects. The Court has even described the principle of precaution as a general principle of EU law. ${ }^{82}$ Another fact that the listed principles have legal effects and are binding ${ }^{83}$ is that the Court has reviewed the validity of Union measures under those principles and, for example, even annulled ${ }^{84}$ a Commission directive that infringed the precautionary principle.

Article 192 TFEU handles the procedural matters in environmental policy. The procedures for adopting legislative acts, which should specify actions to achieve the environmental objectives, and Environmental Action

\footnotetext{
${ }^{75}$ Case C-2/90 Commission v Belgium [1992] EU:C:1992:310, para 34

${ }^{76}$ Case C-480/06 Commission v Germany [2009] EU:C:2009:357, para 37

${ }^{77}$ Kramer (n 61) 27

${ }^{78}$ Langlet and Mahmoudi (n 43) 56

${ }^{79}$ Dir 2004/35/CE of the European Parliament and of the Council of 21 April 2004 on environmental liability with regard to the prevention and remedying of environmental damage [2004] OJ L143/56

${ }^{80}$ ERG and Others (n 64) para 67. See, for analogy, Case C-293/97 Rv Minister of Agriculture, Fisheries and Food, ex parte Standley and Others [1999] EU:C:1999:215, para 51

${ }^{81}$ Langlet and Mahmoudi (n 43) 57

${ }^{82}$ Case T-74/00 Artegodan and Others v Commission [2002] EU:T:2002:283, para 184

${ }^{83}$ Gerd Winter, 'The Legal Nature of Environmental Principles in International, EC and German Law' in Richard Macrory (ed), Principles of European Environmental Law (Europa Law 2004) 19-22

${ }^{84}$ Case T-229/04 Sweden v Commission [2007] EU:T:2007:217, para 262
} 
Programmes are laid down by Article 192(1)-(3) TFEU, while the next provision makes the Member States responsible for financing and implementing the environmental policy without prejudice to certain EU measures. Article 193 TFEU reveals that the protective measures at Union level are subject to only minimum harmonisation. Member States are free to maintain or even introduce more demanding measures with the conditions that they are compatible with the Treaties and notified to the Commission.

Article 37 of the Charter reiterates the objective of a high level of protection and the improvement of the quality of the environment by drawing on, other than the EU Treaties, the provisions of some national constitutions. ${ }^{85} \mathrm{EU}$ secondary law also plays a vital role in the definition and implementation of the environment policy - a 2015 report confirms that the EU environmental acquis amounts to some 500 regulations, directives and decisions. ${ }^{86}$ The policy's basic framework includes non-binding soft law documents, Environmental Action Programmes, horizontal strategies, international environmental cooperation and environmental impact assessment as well.

\subsection{Requirement of Environmental Integration}

EU environmental policy has objectives other than those laid down in Article 191(1) TFEU. A vital characteristic of sustainable development is to integrate environmental concerns into socio-economic policies, as environmental policy, standing alone, has no or little chance to reach its objectives. This integration should be a new development model where social, economic and environmental goals are fully integrated. ${ }^{87}$ Article 11 TFEU states:

Environmental protection requirements must be integrated into the definition and implementation of the Union's policies and activities, in particular with a view to promoting sustainable development.

Article 11 TFEU is not the only integration clause in the Treaties - Title II TFEU hosts other provisions having general application as well. In general, all these integration clauses participate in a common scheme of ensuring that the Union actions are guided by a quality-of-life project. No hierarchy is established among these clauses, however, since Article 11 TFEU is the only horizontal clause pursuing an objective set in Article 3(3) TEU and the fact that environmental requirements must be integrated, rather than "ensured" or "taken account" as in the other clauses, environmental integration is seen as a stronger commitment compared to some other integration clauses. ${ }^{88}$ The provision is also included in Article 37 CFREU and has been marked as a general, ${ }^{89}$ legal $^{90}$ and basic $^{91}$ principle. Improving environmental integration is a priority objective in the Seventh

\footnotetext{
${ }^{85}$ Explanations relating to the Charter of Fundamental Rights [2007] OJ C303/17, explanation on art 37

${ }^{86}$ European Environment Agency, The European Environment - State and Outlook 2015: Synthesis Report (Publications Office of the European Union 2015) 21

87 The European Consultative Forum on the Environment and Sustainable Development, Statement on Environmental Integration (1998)

${ }^{88}$ Saadler, EU Environmental Law and the Internal Market (n 34) 24-25

${ }^{89}$ Martin Wessmaier, 'The Integration of Environmental Protection as General Rule for Interpreting Law' (2001) 38(1) CMLR 159, 161

${ }^{90}$ Nele Dhondt, Integration of Environmental Protection into Other EC Policies: Legal Theory and Practice (Europa Law 2003) 143

${ }^{91}$ Said Mahmoudi, 'Integration of Environmental Considerations into Transport' in Richard Macrory (ed), Reflections on 30 Years of EU Environmental Law (Europa Law 2006) 185
} 
Environmental Action Programme as well, which sets achieving the requirements of the principle as a prerequisite for reaching other priority objectives of the Programme. ${ }^{92}$

One thing this integration clause has in common with other environmental principles is the unclear formulation of its text in the Treaty. No conceptual tools or implementation methods have been given a place in the provision. In general, the provision has been formulated vaguely - it does not provide for what the environmental requirements are, what the integration means and how this integration should be done in practice. It is suggested that the said requirements comprise the objectives, principles and criteria of Article 191 TFEU and the goal of sustainable development. ${ }^{93}$ The emphasis of the sustainable development in Article 11 TFEU also decreases the legal clarity of the provision. ${ }^{94}$ Scepticism towards the functioning of the environmental criteria as environmental protection requirements has been put forward, because, according to Article 191(3) TFEU, they are only "take[n] into account". ${ }^{95}$ On the contrary, environmental protection requirements have been equipped with an even more inclusive meaning as well. ${ }^{96} \mathrm{It}$ is also suggested that the scope of the clause - policies and activities - is not limited to a certain ambit, for example, Title XX TFEU - Environment. ${ }^{97}$

This limited clarity does not, however, strip off the legal nature of the provision. First of all, the clause has been formulated as an obligation and not a mere recommendation. ${ }^{98}$ This makes the clause binding for the EU institutions, while Member States are also bound with it when applying the EU law. ${ }^{99}$ The clause has a real impact on the interpretation and application of EU law. One apparent implication of the integration requirement is that the objectives in other policy areas must be achieved through measures that are as environmentally friendly as possible. ${ }^{100}$ If this is not possible, the indispensability of the measure for achieving an EU objective should be questioned; if negative, the measure may even have to be completely abandoned. ${ }^{101}$ Moreover, environmental integration not only requires the EU institutions to interfere but also invites them to extend the field of environmental action: "policies and activities" in the Treaty provision include all regulatory and financial measures and not only those specifically entitled 'policies' and 'activities'. ${ }^{102}$

The vague wording of the substance does not preclude the EU lawmakers to use the clause as a legal basis for legislative measures either. ${ }^{103}$ Integration of environmental concerns implies that environmental

\footnotetext{
${ }^{2}$ Decision No 1386/2013/EU of the European Parliament and of the Council of 20 November 2013 on a General Union Environment Action Programme to 2020: 'Living well, within the limits of our planet' [2013] OJ L 354/171, paras 85-89 (Union Environment Action Programme to 2020)

${ }^{3}$ Julian Nowag, Environmental Integration in Competition and Free-Movement Laws (OUP 2016) 25

${ }^{94}$ Suzanne Kingston, 'The Role of Environmental Protection in EC Competition Law and Policy' (PhD Thesis, Leiden University 2009 ) 19

${ }_{95}$ Nowag (n 93) , 25

${ }^{96}$ Martin Hession and Richard Macrory, 'The Legal Duty of Environmental Integration: Commitment and Obligation or Enforceable Right' in Timothy O'Riordan and Heather Voisey (eds), The Transition to Sustainability: The politics of Agenda 21 in Europe (Earthscan 1998) 108-109

${ }^{97}$ Toby Schumacher, 'The Environmental Integration Clause in Article 6 of the EU Treaty: Prioritising Environmental Protection' (2001) 3(1) Environmental Law Review 29, 33-34

98 See, eg, Case C-379/98 PreussenElektra [2001] Opinion of AG Jacobs, EU:C:2000:585, para 231

99 Some authors argue contrary. See, eg, Dhondt (n 90) 30

${ }^{100}$ Jan Jans and Hans Vedder, European Environmental Law (4 $4^{\text {th }}$ edn, Europa Law 2012) 22

${ }^{101}$ Dhondt (n 90) 478

102 Saadler, EU Environmental Law and the Internal Market (n 34) 21, 26

103 Schumacher (n 97) 39-41
} 
protection measures can and should be taken in other policy areas and thus, may be based on legal grounds other than Article 192 TFEU. ${ }^{104}$ When Greece challenged the legal basis of a regulation on trade by arguing that since the main purpose of the act was the protection of human health, it should have been based on a provision relating to the environmental policy and not to the trade policy, the Court held that all EU measures, and not only the environmental ones, have to comply with the environmental protection requirements and a measure must not be considered as a part of environmental policy just because it concerns environmental protection. ${ }^{105}$

The Court also has an authority to review compliance of the EU acts with the integration obligation ${ }^{106}$ and to rely on the clause as a principle of interpretation when ruling on other cases. ${ }^{107}$ In 2004 , Austria challenged a regulation before the Court on the ground that the contested act had no or only insufficient integration of environmental requirements. Although the case was not adjudicated by the Court, it is nevertheless interesting to have a look at the Advocate General's views on the matter. According to the Advocate General Geelhoed, although the environmental integration provision is drafted in imperative terms, environmental protection cannot be seen as the governing interest when defining the Union policies and a contrary interpretation would restrict the powers of the EU institutions. The provision can only be regarded as an obligation on the part of the Union institutions to take account of ecological interests in non-environment policies. It may be a ground for reviewing the validity of an EU act only where these interests have been manifestly ignored. ${ }^{108}$

The level of integration required by the provision is also under question. The question of how far the chain of implementation it reaches remains open: adopting secondary legislation or also its application? ${ }^{109}$ Three possible interpretations of integration have been identified: weak, stronger and strong. ${ }^{110}$ The weak ('take into account') interpretation entails that environmental protection requirements should only be taken into account without adjusting the policies. According to the stronger ('observe') interpretation, environmental protection requirements need to be taken into account on an equal level with the sectoral goals. Environmental requirements take precedence in cases of conflict pursuant to the strong ('priority') interpretation. Regardless of the interpretation to be chosen, one could say that integration is more likely to be a means by which the EU aims to reach its objectives and not a goal in itself. But this still does not provide us with the answer of to what degree we should seek this integration in practice. In fact, the environmental integration clause can open a way to several clash scenarios in practice. ${ }^{111}$

\footnotetext{
${ }^{104}$ Langlet and Mahmoudi (n 43) 60

105 Case C-62/88 Greece v Council [1990] EU:C:1990:153, para 20

106 Case C-341/95 Bettati v Safety Hi-Tech [1998] EU:C:1998:353, paras 36-59

107 See, eg, Case C-320/03 Commission v Austria [2005] EU:C:2005:684, para 73; Case C-94/03 Commission v Council [2006] EU:C:2006:2, para 26

${ }_{108}$ Case C-161/04 Austria v Parliament and Council [2006] Opinion of AG Geelhoed, EU:C:2006:66, para 59

109 Schumacher (n 97) 32

110 Dhondt (n 90) 84-98; Suzanne Kingston, 'Integrating Environmental Protection and EU Competition Law: Why Competition Isn't Special' (2010) 16(6) European Law Journal 780, 788

111 Schumacher (n 97) 35-39
} 


\section{ENVIRONMENTAL PROTECTION AS INTEGRATED INTO THE EU STATE AID POLICY}

This chapter focuses on the research question of how (and to what extent) the environmental protection requirements are reflected in the EU State aid policy. To answer this question, characteristics of environmental State aid and the State aid tools through which the environmental protection is taken into account should be studied. First, the environmental State aid policy of the EU, which reveals the conditions, areas and thresholds for granting State aid for the protection of the environment, is briefly described. Next, the focus turns to the existence of environmental State aid - the first stage in the assessment of State support to businesses for environmental matters. Lastly, the compatibility of environmental State aid with the internal market is deeply examined.

\subsection{Introduction to the EU Environmental State Aid Policy}

When going through the Union objectives in Chapter 2, this thesis emphasised, among others, a high level of protection and improvement in the quality of the environment as a vital EU objective under Article 3(3) TEU, which ultimately serves the establishment and functioning of the internal market. The obligation stipulated in Article 11 TFEU to integrate environmental protection requirements into the EU policies has also been covered in Chapter 3. After laying down the fundamentals, this Chapter finally addresses the research question of how the requirements of the EU objective of environmental protection are taken into account and reflected in the EU's State aid policy. The scope of these requirements is not agreed upon. ${ }^{112}$ To address the research question, however, this thesis uses what seems the orthodox view, according to which, the requirements of the EU objective of environmental protection comprise environmental objectives, principles and criteria as laid down by Article 191(1)-(3) TFEU.

In the field of State aid control, the environmental considerations are taken into account, and reflected, through the policy of State aid granted for environmental protection (or the environmental State aid policy). The policy intends to ensure that the State aid control is coherent with the requirements of the EU environmental policy. The overall aim of the environmental State aid policy is to achieve a higher level of environmental protection in the absence of aid and to ensure that the positive effects of the aid outweigh its distortive effects, taking the PPP into account. ${ }^{113}$ EU environmental State aid policy determines the conditions and amount of aid that a Member State can grant to undertakings for environmental protection, as well as the projects eligible for such aid. ${ }^{114}$ In practice, the policy is even able to determine the domestic environmental policy to be implemented

\footnotetext{
112 See Section 3.3.

${ }^{113}$ Marta Villar Ezcurra, 'EU State Aid and Energy Policies as an Instrument of Environmental Protection: Current Stage and New Trends' (2014) 13(4) European State Aid Law Quarterly 665, 666 and 669

114 Francis McGowan, 'Competition Policy: The Limits of the European Regulatory State' in Helen Wallace and William Wallace (eds) Policy-Making in the European Union (4th edn, OUP 2000) 129-130
} 
and the types of energy technologies that should be subsidised. ${ }^{115}$ In parallel, the EU's energy policy has recently become increasingly interrelated with its environmental policy, ${ }^{116}$ as it has developed into a vital tool for promoting environmental protection and combating climate change. ${ }^{117}$ Additionally, the General Block Exemption Regulation gives place to the provisions for energy aids in the section of aid for environmental protection. Taking these into account, energy aid measures that have considerable environmental implications are, where relevant, also covered in this study.

Member States can attempt to address their environmental concerns via various measures supporting businesses. Where these measures serve the organisation and regulation of the national economy, they can be held as not amounting to State aid. However, Member States may also be allowed to grant environmental support measures even if they are found to constitute State aid. The methodology of assessing the existence and the compatibility of environmental State aid, therefore, consists of several steps. It should be recalled that State aid is, in general terms, incompatible with the internal market and thus, prohibited in the EU. The first stage of assessment, therefore, deals with the existence of environmental aid: some State measures that support environmental protection, despite carrying certain aid elements, do not constitute State aid in the sense of Article 107(1) TFEU. Next, if a measure proved to be State aid, it can still be implemented without the Commission approval if the requirements of the General Block Exemption Regulation are complied with. On the other hand, even if the aid measure is not exempted under the Regulation, the Commission can approve it if the requirements of Environmental and Energy Aid Guidelines are met. The compatibility of environmental State aid may also be assessed under tools on emission trading scheme, ${ }^{118}$ stranded costs, ${ }^{119}$ coal matters, ${ }^{120}$ etc., but State measures falling into the scope of these documents are not covered in this study. Finally, if environmental aid measures are not within the aid categories in the Regulation or the Guidelines, they can still be declared by the Commission compatible with the internal market directly under Treaty exemptions.

\subsection{Existence of Environmental State Aid}

Before measuring the ability of a State support measure to reach certain environmental objectives and assessing its compatibility with the internal market, the existence of State aid in the sense of Article 107(1) TFEU must be established. Existence of environmental State aid cannot be proved if an environmental support measure does not meet all conditions of the notion of State aid, which are the presence of economic advantage, State

\footnotetext{
${ }^{115}$ Karoline Flam, 'EU Environmental State Aid Policy: Wide Implications, Narrow Participation?' (2009) 19 Environmental Policy and Governance 336, 336

116 Ezcurra, 'EU State Aid and Energy Policies' (n 113) 666

117 Bacon (n 54) 224

${ }^{118}$ Dir 2003/87/EC of the European Parliament and of the Council of 13 October 2003 establishing a scheme for greenhouse gas emission allowance trading within the Community [2003] OJ L275/32 and Commission, 'Guidelines on certain State aid measures in the context of the greenhouse gas emission allowance trading scheme post-2012' (Communication) SWD(2012) 130 final

${ }^{119}$ Commission, 'Communication relating to the methodology for analysing State aid linked to stranded costs' D/290869

${ }^{120}$ Decision of the Council (2010/787/EU) of 10 December 2010 on State aid to facilitate the closure of uncompetitive coal mines [2010] OJ L336/24
} 
involvement, selectivity, and threat to distort competition and to affect trade between the Member States. ${ }^{121}$ Since the last condition is normally presumed to be met in State aid measures (except for aid amounting less than EUR 200000 over any period of three fiscal years ${ }^{122}$ ), the assessment of the existence of environmental State aid below in this Section is given in relation to the first three conditions.

\subsubsection{Economic advantage}

Economic advantage, a condition of State aid meaning an economic benefit that mitigates the costs which are normally incurred by an undertaking ${ }^{123}$ and often encouraging the attainment of the economic or social objectives sought, ${ }^{124}$ is not conferred and thus, State aid does not exist where a public body, when adopting measures, complies with the normal market conditions. ${ }^{125}$ As a general rule, if the situation of an undertaking is financially improved as a result of State intervention on terms different from normal market conditions, that intervention amounts to an economic advantage. ${ }^{126}$ To determine this, a legal test developed by the EU institutions assesses the causal relationship between the undertaking's financial situation after the State intervention and its situation if the measure had not been taken. ${ }^{127}$ Known as the market economy operator principle, the test, by comparing the public bodies' behaviour to that of similar private economic operators, assesses whether economic transactions carried out by public bodies take place under normal market conditions, and determines whether the economic transactions carried out by those bodies are liable to place a certain undertaking in a more favourable position in comparison with its competitors by granting to it an economic advantage ${ }^{128}$ and thus, constitute State aid. ${ }^{129}$ Advocate General Slynn explains the nature of state interventions in the economy as follows:

It is of the essence of a State aid that it is non-commercial in the sense that the State steps in where the market would not. The State may have its reasons for doing so but they are not commercial in the ordinary sense of the word. Thus the State may subscribe for shares in a company or lend money, but when it does so to an extent or on terms which would not be acceptable to the commercial investor, it is granting aid which falls within Article [107] if the tests of that provision are satisfied.

\footnotetext{
121 See, eg, Commission Decision (C(2014) 5080) (EU) 2015/1226 of 23 July 2014 on State aid SA.33963 (2012/C) (ex 2012/NN) implemented by France in favour of Angouleme Chamber of Commerce and Industry, SNC-Lavalin, Ryanair and Airport Marketing Services. See also Marie Sciskalova and Michael Munster, 'Definition and Characteristics of State Aid', (2014) 110 Procedia - Social and Behavioral Sciences 223,224

122 Commission Regulation (EU) No 1407/2013 of 18 December 2013 on the application of Articles 107 and 108 of the Treaty on the Functioning of the European Union to de minimis aid [2013] OJ L352/1, art 3(2)

${ }^{123}$ Case C-30/59 De gezamenlijke Steenkolenmijnen in Limburg v High Authority [1961] EU:C:1961:2, 19

${ }_{124}$ Case C-61/79 Amministrazione delle finanze dello Stato v Denkavit italiana [1980] EU:C:1980:100, para 31

${ }^{125}$ Case C-39/94 SFEI and Others [1996] EU:C:1996:285, paras 60, 61

${ }^{126}$ Commission, 'Notice on the notion of State aid as referred to in Article 107(1) of the Treaty on the Functioning of the European Union' C/2016/2946, para 67

${ }^{127}$ Case C-173/73 Italy $v$ Commission [1974] EU:C:1974:71, para 13

128 See, eg, Case C-387/92 Banco Exterior de España v Ayuntamiento de Valencia [1994] EU:C:1994:100, para 14

${ }^{129}$ Commission, 'Notice on the notion of State aid' (n 126) para 75
} 
It follows from the market economy operator principle, and as implied by the principle of equal treatment between public and private undertakings, that where the State acts as a private undertaking would, Article 107(1) TFEU is not involved. ${ }^{130}$ This is true with respect to environmental State measures as well. State intervention for environmental protection does not amount to State aid in the meaning of Article 107(1) TFEU if the intervening State authority only acts as a market operator in carrying out that intervention.

The question of economic advantage has been raised in numerous State aid cases. In one of them, the Commission held that a public-private partnership project to construct and operate an energy plant in Ireland did not amount to an economic advantage to undertakings by the State investment. The Commission concluded that the State intervention in question fell outside Article 107(1) TFEU as it was proven that a private market economy operator acting under normal market conditions would have invested in the said project. ${ }^{131}$ The payment of indemnities to undertakings collecting and disposing of waste oils amounted to compensation for the services performed by such undertakings rather than State aid. ${ }^{132}$ Similarly, since the undertakings did not receive any advantage and were granted only fair remuneration for their activities, a Dutch measure through which recycling undertakings were paid a grant to collect and dispose of car wrecks did not constitute aid. ${ }^{133}$ The Commission held, pursuant to the PPP, that a grant for the decontamination of an old industrial site did not confer an economic advantage on the present owner of the site as it was not responsible for the pollution. ${ }^{134}$

The list of cases where the measures were found by the Commission not State aid can be further extended. In some cases, however, the Member States' environmental concerns and the Union's interest in State aid control do not get along well. In such situations, environmental objectives pursued by the Member States can be obstructed by EU State aid rules. For example, German government's financing of the elimination of industrial dust emitted by an undertaking constituted State aid because it effectively exempted the receiving undertaking from internalising the costs it would bear in normal conditions - in the absence of aid. ${ }^{135}$ Since energy infrastructure, the construction and operation of which constitutes an economic activity, is usually built by private market players and financed through the service users, funding by the UK of energy infrastructure by public resources was presumed to be subject to the State aid rules. ${ }^{136}$ Another case saw the Commission stating that constructing regular, in contrast to reserve, electricity generation capacities cannot amount to an obligation of services of general economic interest and constitutes an economic advantage conferred by the Irish government on private undertakings. ${ }^{137}$

\footnotetext{
${ }^{130}$ Case C-303/88 Italy v Commission [1991] EU:C:1991:136, para 19, 20

${ }^{131}$ Commission Decision (C(2014) 2247 final) State aid SA.36591 (2014/NN) - Ireland: Alleged aid to waste-to-energy facility [2014] paras 111-122

${ }^{132}$ ADBHU (n 33) para 18

133 Kingston, Greening EU Competition Law and Policy (n 55) 382

${ }^{134}$ European Commission, XXVIII Report on Competition Policy (Office of Official Publications of the European Communities 1998 ) 256

135 Commission Decision 1999/227/ECSC on aid granted by the Land of Lower Saxony (Germany) to Georgsmarienhütte GmbH [1997]

${ }^{136}$ Commission, 'Notice on the notion of State aid' (n 126) para 217; Commission Decision (C(2014) 4939 final) State aid SA.36290 (2014/N)

- UK: Northern Ireland Gas Pipeline; extension to the West and the North West [2014] paras 6, 16, 21, 22

137 Commission Decision (C(2003) 4488 fin) State aid N 475/2003 - Ireland: Public Service Obligation in respect of new electricity generation capacity for security of supply [2003] para 35. See also Commission Decision (C(2010) 4146) State aid 675/2009 - Tender for Aid for New Electricity Generation Capacity (LV) [2010]
} 
Despite its firm position in these last indicated cases, it can be said that the Commission's approach to the economic advantage criterion in environmental support measures is well-defined and targeted. In the majority of cases, it is the PPP that the Commission takes into consideration in examining whether undertakings receive an advantage with the implementation of those measures. ${ }^{138}$ The principle has the effect of precluding the Member States from remedying environmental damages through public resources. At first sight, this may seem as hampering a high level of environmental protection and holding back a speedy recovery of the environment, but the principle, at the same time, holds the polluters responsible and indirectly prevents even bigger amounts of pollution. That is why the Commission's reliance on the PPP when assessing the economic advantage criterion is quite sensible.

However, the Commission can still apply the State aid rules less strictly to an extent not contrary to the Treaties to allow addressing even more environmental concerns. This 'mild' assessment of economic advantage criterion should be applied in the examination of not all measures, but only those environmental support measures that can effectively bring about environmentally friendly outcomes. This approach would lead to the finding of an economic advantage conferred on undertakings, and thus, of Stat aid, in fewer cases, which would ultimately allow the Member States to prevent or remediate more environmental problems. Moreover, when applying the market investor principle the Commission should also take due account of widespread and significant changes in the private sector's attitude towards voluntary corporate environmental initiatives. ${ }^{139}$

\subsubsection{State resources}

The next State aid condition to consider in the examination of the existence of environmental State aid is the use of State resources. A support measure does not amount to the State aid if no direct or indirect State resources, ${ }^{140}$ or in other words, a burden on the public finances in the form of either expenditure or reduced revenue, ${ }^{141}$ are involved. The State has a wide meaning in the sense of Article 107(1) TFEU: it covers not only federal and central authorities, but also regional and local levels of government, ${ }^{142}$ and even public-private partnership. ${ }^{143}$ Therefore, the term "State resources" has also been interpreted broadly to include, among others, all public sector resources, ${ }^{144}$ funds and assets of intra-State entities (autonomous or not). ${ }^{145}$

The use of State resources is also a precondition for environmental State measures to be considered as State aid. In other words, State measures adopted for environmental protection do not amount to State aid in the meaning of Article 107(1) TFEU if the benefitting undertakings do not receive special treatment through the

\footnotetext{
138 Saadler, EU Environmental Law and the Internal Market (n 34) 439

139 Kingston, Greening EU Competition Law and Policy (n 55) 381-382

${ }^{140}$ Case C-82/77 Van Tiggele [1978] EU:C:1978:10, paras 25, 26

${ }^{141}$ Case C-82/77 Van Tiggele [1978] Opinion of AG Francesco Capotorti, EU:C:1977:205, 52

${ }^{142}$ Case C-248/84 Germany $v$ Commission [1987] EU:C:1987:437, para 17

${ }^{143}$ Commission Decision (C(2013) 87) State aid SA.24123 (2012/C) (ex 2011/NN) implemented by the Netherlands Alleged sale of land below market price by the Municipality of Leidschendam-Voorburg [2013] para 65

144 T-358/94 Air France v Commission [1996] EU:T:1996:194, para 56

145 Joined Cases T-228/99 and T-233/99 Westdeutsche Landesbank Girozentrale v Commission [2003] EU:T:2003:57, paras 178-183
} 
burden on State resources. Similar to the condition of economic advantage, the criterion of transfer of State resources is also checked with the PPP in mind, in light of which, the support granted by Austria to an undertaking to cover its costs of cleaning up the contaminated soil did not involve a transfer of State resource, because the beneficiary undertaking was bound to reimburse the sum to the State budget. ${ }^{146}$ Green energy purchase obligations, which impose on private electricity suppliers the requirement of purchasing electricity from renewable resources at set minimum prices, have also been under judicial scrutiny. In one of the cases questioning the compatibility of this kind of obligation with the State aid rules, the Court held that, although the measure granted an apparent economic advantage on the renewable energy suppliers, it did not involve any transfer of State resources or loss of possible revenue as the payment for the said purchase was made entirely by the private electricity supply companies from their resources. ${ }^{147}$ The Commission adopted this position when examining the Belgian green certificates and decided that the measure did not constitute advantage from State resources because it was the distributors the transfer of resources emanated from and not the State. ${ }^{148}$

A conflict between two legitimate interests of the EU - an internal market without competitive distortions and a high level of environmental protection and improvement - can occur in cases where the question of State resources is raised. Both the Court and the Commission have recently distinguished their approach towards green energy purchase obligations to find that an electricity purchase obligation involves State resources where (i) it is financed through a levy imposed on electricity consumers or suppliers, (ii) the State devotes that levy a specific purpose and designates a body (even a private law entity ${ }^{149}$ ) to manage the process ${ }^{150}$ and (iii) the entity purchasing greener electricity forms part of the State. ${ }^{151}$ An aid scheme in the Netherlands allowing undertakings to trade allowances for the emission of nitrogen oxide involved State resources because the Netherlands, instead of selling those allowances or putting them up for an auction, made them available for private undertakings free of charge and therefore, forwent public resources. ${ }^{152}$ In a similar case, since a potential revenue, which the UK could have earned by auctioning emissions trading allowances, was waived away, the allocation of such allowances constituted an advantage granted from State resources. ${ }^{153}$

As can be seen, the Commission and the Court found some State measures involving State resources and some not. However, the inspection of a measure under this criterion should not be limited to examining the presence of State resources' transfer. Article 107(1) TFEU prohibits not only aid granted "through State resources", but also aid granted "by a Member State" in general. This means that measures imputable to the State should be subject to the State aid rules. A measure does not necessarily need to be financed from State

\footnotetext{
${ }^{146}$ Commission Decision 1999/272/EC on the measure planned by Austria for the clean-up of the KienerDeponie Bachmanning landfill [1999]

${ }^{147}$ Case C-379/98 PreussenElektra [2001] EU:C:2001:160, paras 60, 61

148 European Commission, XXXI Report on Competition Policy (Office of Official Publications of the European Communities 2001 ) para 363 149 Case T-251/11 Austria v Commission [2014] EU:T:2014:1060, paras 67-70

150 Case C-262/12 Vent De Colère and Others [2013] EU:C:2013:851, paras 25-37; Commission Decision (C(2014) 7142) 2015/658 on the aid measure SA.34947 (2013/C) (ex 2013/N) which the UK is planning to implement for support to the Hinkley Point C nuclear power station [2014], in particular paras 336-339

${ }^{151}$ Commission Decision $(\mathrm{C}(2008)$ 2223) C 41/05 on the State aid awarded by Hungary through power purchase agreements [2008] para 289

152 Case C-279/08 P Commission v Netherlands [2011] EU:C:2011:551, para 107

${ }^{153}$ Commission Decision (C(2001) 3739 fin) N 416/2001 - UK: Emission Trading Scheme [2001] 9
} 
resources to constitute State aid, ${ }^{154}$ in applying which regard must primarily be had to the effects of the measure on the benefiting undertakings. ${ }^{155}$ If State conduct favours an undertaking, that conduct must be subject to State aid rules, regardless of the source of its financing. ${ }^{156}$ Although they have distinguished their position subsequently, the Commission's and the Court's view of green energy purchase obligations and green certificates should be reconsidered, even if it results with a larger scope for State aid prohibition and potentially, with falling of more environmental support measures into the scope of Article 107(1) TFEU.

\subsubsection{Selectivity}

The environmental support measures are not caught by Article 107(1) TFEU if they are not favouring certain undertakings - to be construed as State aid, a measure must grant an advantage in a selective way to certain undertakings or the production of certain goods. Known as the selectivity criterion, ${ }^{157}$ the condition serves to determine whether a State measure favours certain undertakings compared to other undertakings which are in a comparable legal and factual situation, ${ }^{158}$ for which, the beneficiary's situation after receiving the aid in comparison with its situation as it previously stood is not relevant. ${ }^{159}$

When it comes to the State measures adopted for environmental purposes in particular, they do not amount to State aid in the meaning of Article 107(1) TFEU if those measures apply to all undertakings active in the adopting Member State or do not selectively favour certain undertakings. A widespread instance of these measures is the exemption from environmental taxes. These exemptions have been allowed in some cases, ${ }^{160}$ but this does not mean that the environmental protection purposes automatically 'save' the State measures from falling into the scope of Article 107(1) TFEU. ${ }^{161}$ In other cases, although the State measures for environmental protection favoured some undertakings and granted an economic advantage to them, those measures held to be not selective as the favoured and other beneficiaries were not in a comparable legal and factual situation. ${ }^{162}$

Previously described conflicts between environmental interests and State aid control can be observed in relation to the selectivity condition as well. A Spanish scheme granted support to small and medium-sized enterprises for purchasing environmentally-friendly vehicles but not to large undertakings. Spain argued that since large enterprises could afford to purchase such vehicles without State support, the measures in question were not selective and thus, did not constitute State aid. The Court held that this was not a valid objective

\footnotetext{
${ }_{154}$ Case C-290/83 Commission v France [1985] EU:C:1985:37, para 14

${ }^{155}$ Case C-78/76 Steinike $\mathcal{E}$ Weinlig [1977] EU:C:1977:52, para 21

156 Case C-72/91 Sloman Neptun v Bodo Ziesemer [1993] Opinion of AG Marco Darmon, EU:C:1992:130, 40-41

157 Case C-66/02 Italy v Commission [2005] EU:C:2005:768, para 94

158 Case C-143/99 Adria-Wien Pipeline and Wietersdorfer E Peggauer Zementwerke [2001] EU:C:2001:598, para 41

${ }^{159}$ Case C-57/86 Greece v Commission [1988] EU:C:1988:284, para 10

160 See, eg, Commission Decision (C(2015) 9344 final) SA.43301 (2015/N) - Sweden Tax exemptions and tax reductions for liquid biofuels [2015]

${ }^{161}$ Case C-487/06 P British Aggregates v Commission [2008] EU:C:2008:757, para 92

162 Case C-5/14 Kernkraftwerke Lippe-Ems [2015] EU:C:2015:354, para 79; Commission Decision (C(2013) 1510 final) SA.34880 (2012/N) Denmark: Restructuring of the tax on plant protection products and simplification of the tax on biocides [2013]
} 
justification for treating large undertakings and others differently and that the measure amounted to aid. ${ }^{163}$ In another case, the Court emphasised that even if all facilities were subject to emission reduction obligations in the Netherlands, this was insufficient to wipe out the selective treatment towards 250 largest polluting plants as this was not inherent to the general scheme for reducing pollution. ${ }^{164} \mathrm{In}$ an aggregate levy case, the Commission decided that the differential treatment among the undertakings is not selective if it is in line with the nature and logic of the system. ${ }^{165}$ But this conclusion was overturned by the judgment of the Court. ${ }^{166}$

Selectivity is the most difficult condition of the concept of State aid to be proved in practice. ${ }^{167}$ It may be particularly complex to assess when energy taxes are concerned. ${ }^{168}$ After a careful examination, even interventions which, at first appearance, address undertakings in general may, at least to a certain extent, be selective and, therefore, be regarded as measures designed to favour certain undertakings. ${ }^{169}$ As the instances in the preceding paragraph also show, the Commission's wide discretion in the assessment of the selectivity condition can, in many cases, result with a low-level integration of environmental protection into the State aid policy. Of course, the selectivity criterion, as an element of the State aid notion, must be taken due account when assessing State support measures, however, the selectivity examination of measures in such a strict way can lead more and more amounts of such measures to fall into the scope of Article 107(1) TFEU. This, in turn, may well discourage the Member States to tackle the environmental problems via support to private undertakings and to achieve their environmental targets. That is why, as suggested with regard to the economic advantage criterion, a more 'tolerant' position in assessing the selectivity criterion would result with more environmental considerations taken into account and reflected in the State aid decisions and judgments.

\subsection{Compatibility of Environmental State Aid}

\subsubsection{General Block Exemption Regulation}

If State aid is found to be existing in the meaning of Article 107(1) TFEU, the Commission, as a general rule, assesses its compatibility with the internal market as the next step. Per Article 108(3) TFEU, Member States must inform the Commission, who has exclusive competence to assess the compatibility of the State measures and authorise the aid, of any plans to grant aid to undertakings. The provision also requires the Member States not to put their proposed measures into effect until this notification procedure has resulted in a final decision (known as the 'standstill obligation'). The EU State aid policy has developed, and continues to do so, through, among others, assessment of the aid measures adopted by the Member States thanks to these notification and standstill obligations. However, this provision did not preclude the Commission to introduce the General Block

\footnotetext{
163 Case C-409/00 Spain v Commission [2003] EU:C:2003:92, para 53

${ }^{164}$ Commission $v$ Netherlands (n 152) para 76

${ }^{165}$ Commission Decision (C(2002) 1478 final) on State aid file N 863/01 - UK: Aggregates Levy [2002] para 34

${ }_{166}$ Case T-210/02 British Aggregates v Commission [2012] EU:T:2006:253, para 101

167 Opinion of AG Jacobs (n 98) para 157

${ }^{168}$ Marta Villar Ezcurra, 'Energy Taxation and State Aid Law' in Isabelle Richelle, Wolfgang Schön and Edoardo Traversa (eds), State Aid Law and Business Taxation (Max Planck Institute Studies in Tax Law and Public Finance, vol 6, Springer 2016) 206

169 Case C-241/94 France v Commission [1996] EU:C:1996:353, paras 23, 24
} 
Exemption Regulation ('GBER' or the 'Regulation'). ${ }^{170}$ Following the adoption of the Regulation, the Member States now are not required to notify the Commission of their plans to grant aid to undertakings and are free to implement it without an authorisation decision if the planned aid falls into the scope of the GBER and fulfils certain conditions. The Regulation was intended to enhance transparency, strengthen the legal certainty in the field of State aid control to the benefit of Member States, businesses, competition lawyers and economists ${ }^{171}$ and reduce the Commission's workload to some extent. ${ }^{172}$ Section 7 of the GBER is allocated to aid for environmental protection. Although the title suggests otherwise, the Section includes not only environmental but also energy aid measures exempted from the notification procedure. Except for reductions in environmental taxes and aid for environmental studies, the Regulation sets individual notification thresholds below which the notification of individual environmental aid is exempted.

As per Article 288 TFEU, the legal status of the GBER is such that it is directly applicable in the Member States and therefore, national authorities can rely on it in granting aid, while competitors of the beneficiary undertaking can require compliance with it by bringing proceedings in the national courts. The legal effect of the Regulation, on the other hand, is to exempt aid from the notification requirement in Article 108(3) TFEU so that it becomes compatible with Article 107(3) TFEU. ${ }^{173}$ Although the GBER and its conditions must be interpreted strictly, the Regulation does not require that the aid measure must contain an express reference to the relevant provisions therein. ${ }^{174}$ The Regulation only applies to aid that is transparent and that has an incentive effect, the latter entailing the submission by the beneficiary of a written aid application to a Member State before the start of work on the project or activity.

The Regulation has a special place in the protection and improvement of the environment in the EU. As an answer to the research question of this study, it can be said that the adoption of the GBER and block exemption of certain aid categories under it certainly serve to reflect the environmental protection requirements in the EU State aid policy. It removes some 'barriers' in front of the Member States for supporting private undertakings to address the environmental challenges they face. The notification thresholds set by the GBER for State aid for environmental purposes, which are the maximum limit for the application of environmental block exemptions, range from EUR 15 million to EUR 150 million per year. This amount is not small in terms of State support for environmental protection and thus, Member States can enjoy the exemptions presented by the Regulation to address the environmental and energy concerns as long as the aid does not exceed the set limits. Moreover, the Regulation, by block exempting certain categories of environmental aid, not only relieves the Member States from notifying the Commission about their plans to grant aid and from 'standing still' until a final decision but also 'encourages' them to intervene in the economy for environmental purposes when market mechanisms cannot prevent or remove market failures and address their environmental concerns. This can only

\footnotetext{
170 Commission Regulation (EU) No 651/2014 of 17 June 2014 declaring certain categories of aid compatible with the internal market in application of Articles 107 and 108 of the Treaty [2014] OJ L187/1

${ }^{171}$ Ulrich Schwalbe, 'European State Aid Control - State Aid Action Plan' in Jurgen Basedow and Wolfgang Wurmnest (eds), Structure and Effects in EU Competition Law: Studies on Exclusionary Conduct and State Aid (Kluwer Law International 2011) 168

${ }_{172}$ Alberto Heimler, 'State Aid Control: Recent Developments and Some Remaining Challenges' in Pier Luigi Parcu, Giorgio Monti, Marco Botta (eds), EU State Aid Law: Emerging Trends at the National and EU Level (Edward Elgar 2020) 55

173 Bacon (n 54) 102 and 155

${ }^{174}$ Dilly's Wellnesshotel (n 59) paras 37, 51
} 
be regarded as a positive step towards effective integration of environmental protection requirements into the State aid control as it paves the way for a deeper concentration on environmental objectives, for a better application of environmental principles and criteria, and thus, for a more consistent approach to the implementation of the sustainable development goals within the area of State aid policy.

\subsubsection{Environmental and Energy Aid Guidelines}

As discussed earlier, although Article 107 TFEU prohibits State aid distorting competition in the internal market and affecting trade between the Member States, that Article also allows the Commission to consider State aid to facilitate the development of certain economic activities compatible with the internal market, if such aid does not adversely affect trading conditions to an extent contrary to the common interest. Where an environmental support measure, which is held constituting State aid, does not fall into the scope of the GBER, the Commission may examine and authorise that measure under the Environmental and Energy Aid Guidelines ('EEAG' or the 'Guidelines').175

The vagueness of the Treaty State aid rules drove the Commission to develop the exemption criteria through soft law instruments, including the EEAG in the area of environmental protection. ${ }^{176}$ Unlike the previous guidelines, the current EEAG do not divide the aid measures to be examined under standard and detailed assessment procedures. The EEAG provide the criteria for aid for environmental protection and energy objectives that are subject to the notification obligation where it does not fall within the scope of the GBER. The Guidelines apply to aid granted with environmental purposes in all sectors governed by the TFEU. Individual environmental aid granted as a part of an environmental aid scheme must be notified to the Commission pursuant to Article 108(3) TFEU if it exceeds the certain notification thresholds determined in the Guidelines.

Overall, the Guidelines play an important role in the protection and improvement of the environment in the EU by deeply concentrating on environmental objectives, and applying the environmental principles and criteria, and implementing the sustainable development goals of the Union. The EEAG extend the already large possibilities of granting certain types of environmental aid under the GBER. This, in turn, allows reflecting even more environmental considerations in the State aid policy. The Guidelines stress both the crucial role that State aid can play in reaching the EU environmental objectives and the significance of integration between the EU's State aid, environment and energy policies. In parallel, the EEAG not only specify the Commission's approach to the environmental and energy aid but also elaborate on the general analytical framework adopted in other cases building the foundation for the different categories of aid contained in the Guidelines. ${ }^{177}$

The EEAG are not just another document specifying the conditions for the compatibility assessment of environmental aid, but they are also a product of a long term planning of providing the Union with a better level

\footnotetext{
${ }^{175}$ Commission, 'Guidelines on State aid for environmental protection and energy 2014-2020' (Communication)

${ }^{176}$ Michael Blauberger, 'From Negative to Positive Integration? European State Aid Control through Soft and Hard Law', Discussion Paper 08/4, (2008) Max Planck Institute for the Study of Societies, 6

177 Nowag (n 93) 191
} 
of environmental protection and energy security: the Commission has set a number of headline targets to reach the objective of creating the conditions for smart, sustainable and inclusive growth in the Union. ${ }^{178}$ To support achieving targets for climate change and energy sustainability, a flagship initiative has been put forward, which, in turn, delivered a roadmap to achieve resource efficiency in the EU. ${ }^{179}$ The roadmap calls for phasing out the environmentally harmful subsidies that confer an advantage on certain producers to supplement their income or lower their costs and that, in the long-term view, decline the level of environmental protection and improvement. ${ }^{180}$ The Guidelines consider these negative impacts of environmentally harmful subsidies, but also take into account the need to bring a compromise between different policy areas as indicated in the flagship initiative. The Commission has also proposed other energy and climate objectives to be met by $2030 .{ }^{181}$ By respecting the commitment, approach and principles set in that proposal, the EEAG lay out the conditions for compatibility of environmental and energy aid with the internal market.

Now, after general acquaintance with the Regulation and the Guidelines, and with their place in integrating requirements of the EU environmental policy into the State aid rules, the study goes through various categories of environmental and energy aid and analyse how the EU objective of environmental protection and the environmental requirements arising out of it are taken into account and reflected in those instruments.

\subsubsection{Environmental Protection in Certain Aid Categories}

Aid for going beyond, or early adaptation to, Union environmental standards

Aid for going beyond Union standards or increasing the level of environmental protection in the absence of Union standards and aid for early adaptation to future Union standards (Article 36-37 GBER) may have a significant impact on improving the environmental conditions and thus, contribute to a higher level of environmental protection in the EU. Both the Regulation and the Guidelines define environmental protection as actions aimed at remedying or preventing the beneficiary's damage to physical surroundings or natural resources, reducing the risk of such damage and leading to more efficient use of natural resources (and not as actions just for preventing "black smoke coming out of an industrial factory"182). The Union standards, on the other hand, are defined as mandatory EU standards setting the levels to be attained in environmental terms by individual undertakings, and the obligation ${ }^{183}$ to use the best available techniques and to ensure that emission levels of pollutants are not higher than they would be when applying those techniques.

\footnotetext{
178 Commission, 'Europe 2020: A strategy for smart, sustainable and inclusive growth' (Communication) COM(2010) 2020 final, 11

${ }_{179}$ Commission, 'A resource-efficient Europe - Flagship initiative under the Europe 2020 Strategy' (Communication) COM(2011) 21 final, 11

${ }^{180}$ Commission, 'Roadmap to a Resource Efficient Europe' (Communication) COM(2011) 571 final, 9-10. See also Conclusions of the European Council (EUCO 75/1/13 REV 1) [2013] 3

${ }^{181}$ Commission, 'A policy framework for climate and energy in the period from 2020 to 2030' (Communication) COM(2014) 15 final, 5-12 182 Birgitte Andersen, 'Revision of Environmental Guidelines', (2008) 17(1) European Energy and Environmental Law Review 23, 29

183 As provided for by Dir 2010/75/EU of the European Parliament and of the Council of 24 November 2010 on industrial emissions (integrated pollution prevention and control) [2010] OJ L334/17
} 
Investment aid to undertakings to go beyond EU environmental standards or to increase the level of environmental protection in the absence of such standards can be compatible with Article 107(3) TFEU and exempt from the notification obligation under 108(3) TFEU if it enables the beneficiary to increase the level of environmental protection by going beyond the applicable Union standards, even if the national standards are more stringent. Aid awarded for State measures for going beyond or adapting the environmental standards that would have been implemented in any event is not exempted, at least under these categories. Aid for early adaptation to future environmental standards, on the other hand, may be compatible with Article 107(3) TFEU where investments to undertakings aim to encourage them to comply with new EU standards which are not yet in force and increase the level of environmental protection. For this, the said investment must be implemented and finalised at least one year before the concerned EU environmental standard enters into legal force.

The quality of the environment can be improved thanks to both categories of aid, which serve the objectives of a high level of the quality of the environment in general and the environmental objectives and principles enshrined in Article 191 TFEU in particular. Although aid to support undertakings to meet their obligations arising out of EU environmental standards is not allowed, the GBER authorises the Member States to help private undertakings to meet national environmental requirements that are even stricter compared to the Union standards. This is a clear instance of reflecting environmental considerations in the State aid rules.

\section{Aid for energy efficiency}

All types of aid that can be combined under the umbrella of aid for energy efficiency - aid for energy efficiency projects in buildings, aid for high-efficiency cogeneration and aid for the installation of energyefficient district heating and cooling systems - enable the receiving undertakings to contribute to the EU goal of sustainable energy efficiency (Articles 38-40 and 46 GBER, Section 3.4 EEAG). Investment aid enabling undertakings to achieve energy efficiency is allowed and exempted under both instruments, according to which, energy efficiency is an amount of saved energy determined by measuring or estimating consumption before and after implementation of an energy-efficiency improvement measure while ensuring normalisation for external conditions that affect energy consumption.

The existence of the contribution to an increased level of environmental protection is essential for the Commission to allow the aid as compatible with the internal market and to demonstrate this, the granting State may use various indicators, including how lower energy performance and higher energy productivity lead to saving energy or the way reduced energy consumption and fuel input pave the way for efficiency gains. The Guidelines urge the energy efficiency measures adopted by the Member States to create incentives for achieving environmental targets such as energy-efficiency and the reduction of greenhouse gas emissions. The aid for

energy-efficiency is proportionate only if it is limited to compensating for net extra production costs resulting from the investment.

When energy-efficiency measures in buildings are considered in particular, since these measures are usually more beneficial for the tenants rather than the building owner, the Commission may find the measures 
as justified State intervention. Moreover, EU law imposes an obligation on the Member States to mobilise investment for energy-efficiency in the renovation of buildings. ${ }^{184}$ Since this obligation does not apply to undertakings, the Commission does not prevent aid in the field of energy-efficiency from having an incentive effect.

Environmental aid for high-efficiency cogeneration is also eligible for exemption. Cogeneration means the generation of thermal energy and electrical or mechanical energy simultaneously in one process. As a more sustainable model, high-efficiency cogeneration provides primary energy savings of at least $10 \%$ compared with the references for separate production of heat and electricity. ${ }^{185}$ The aid is deemed compatible only if it is granted for newly installed or refurbished capacities: the newly installed cogeneration unit must provide overall primary energy savings compared to separate production of heat and electricity, ${ }^{186}$ while the capacities refurbished by improving an existing cogeneration unit or converting an existing power generation unit into a cogeneration unit must bring primary energy savings compared to the original situation. Investment aid for the installation of energy-efficient district heating and cooling system ${ }^{187}$ also benefits from the exemption. The aid may be granted either for the energy production plant or the distribution network that are necessary to distribute the heat and cooling from the production units to the customer premises. Aid for high energy-efficient cogeneration plants, and combined heat and power installations may be granted only (i) to undertakings generating electric power and heat to the public if the production cost exceeds their market price and (ii) for the industrial use if the production cost exceeds the market price of conventional energy.

Aid for energy efficiency brings a higher level of environmental protection even closer by promoting environmental objectives of prudent and rational utilisation of natural resources, combating climate change, and sustainable development, and abiding by the environmental principles under Article 191 TFEU. The aid allows the Member States to effectively overcome energy efficiency problems in their territories by providing a certain amount of aid to market participants.

\section{Aid to energy from renewable sources}

Aid for energy efficiency from renewable sources (Article 41 GBER, Section 3.3 EEAG) promotes the EU sustainable development goals and the environmental objectives of prudent and rational utilisation of natural resources and combating climate change under Article 191(1) TFEU. The more energy from renewable energy sources, the better the EU combats climate change by cutting greenhouse gas emissions and replacing unsustainable energy. ${ }^{188}$

\footnotetext{
${ }_{184}$ Dir 2012/27/EU of the European Parliament and of the Council of 25 October 2012 on energy efficiency, amending Directives 2009/125/EC and 2010/30/EU and repealing Directives 2004/8/EC and 2006/32/EC [2012] OJ L315/1, art 4

185 ibid Annex II (a)

186 ibid

187 ibid art 2(41) and (42)

${ }_{188}$ Raf Callaerts, 'State Aid for the Production of Electricity from Renewable Energy Resources', (2015) 24(1) European Energy and Environmental Law Review 17, 17
} 
Energy from renewable sources is defined as energy produced by plants using only renewable energy sources and energy produced from renewable energy sources in hybrid plants which also use conventional energy sources. The investment aid for energy from renewable sources addresses the risks of insufficient electricity generation capacities. To allow the Member States to achieve their energy sustainability goals, the aid granted for energy from renewable sources is presumed already appropriate and having limited distortive effects if all other conditions are met. However, the Commission acknowledges the need to phase out the environmental subsidies and environmental responsibility exemptions in a degressive way, and ensures the transition to the cost-effective use of renewable sources through market-based mechanisms. Operating aid for the similar purpose - the promotion of electricity from renewable energy sources is also exempted where it is granted to new and innovative renewable energy technologies as a result of a competitive bidding process based on clear, transparent and non-discriminatory criteria.

New and innovative renewable energy technologies are new and unproven technologies compared to the state of the art in the industry, which carry a risk of technological or industrial failure and are not optimisation or scaling up of existing technologies. A transparent and non-discriminatory competitive bidding process, on the other hand, is a market instrument which normally ensures that environmental State aid is limited to the minimum. To grant aid following a competitive bidding procedure, there should be sufficient competition between the participating undertakings to incentivise lower prices and low regulatory costs to avoid barriers to market entry. All renewable electricity generators competing on equal footing should, in principle, be allowed to bid for the aid on a non-discriminatory basis. If the aid is granted following a clear, transparent and non-discriminatory competitive bidding process open to all renewable electricity generators, the Commission presumes that the aid is proportionate enough and does not materially distort competition. However, aid may be granted to specific technologies without such bidding processes.

The Commission differentiates a few types of support to renewable energy, one of which is green certificates. Green certificates allow renewable energy generators to benefit from guaranteed demand for their energy at a market price higher than the price of conventional power, but also expose them to the efficiency of market prices. The Commission welcomes this market mechanism as long as it is essential to ensure the viability of the renewable energy sources, does not result in overcompensation and does not dissuade renewable energy producers from becoming more competitive. State aid for renewable energy can also be used by the receiving undertakings to fully internalise the costs of greenhouse gas emissions. Aid for the production of hydropower may also be considered as contributing to a higher level of environmental protection provided that the granting State respects the relevant provisions of the EU law. ${ }^{189}$ Unlike other sources of renewable energy, biomass requires relatively low investment and higher operating costs. To maintain the use of biomass, the Commission may allow operating aid even after plant depreciation. For the aid to be authorised, the granting State should demonstrate that the cost incurred by the aid recipient after the depreciation of the plant is still higher than the market price or that the use of fossil fuels as input is more economically advantageous than the use of biomass. In both cases, the measure should compensate for the price or cost difference in-between.

\footnotetext{
${ }^{189}$ Dir 2000/60/EC of the European Parliament and of the Council of 23 October 2000 establishing a framework for Community action in the field of water policy [2000] OJ L327/1. See, in particular, art 4(7)
} 
The EU policy of promoting renewable energy through granting environmental State aid has now long contributed to the competitiveness of renewable energy sources. ${ }^{190}$ Several forms of renewable energy sources have, therefore, become mature competitive and they are no longer in need of public financial support. Thus the EEAG respond by imposing more stringent compatibility conditions for renewable energy support measures, the aim being to make renewable energy more efficient and better market-integrated. ${ }^{191}$

Discussing the aid to energy from renewable sources is a perfect excuse to remember the mandatory national targets for the use of renewable energy, ${ }^{192}$ which are in line with the EU goal to have an increase of $20 \%$ in its sustainable energy efficiency by $2020 .{ }^{193}$ As a part of those targets, Member States must ensure that at least $10 \%$ of the overall energy consumption in transport comes from renewable energy sources. Member States are also required to achieve a $40 \%$ cut in greenhouse gas emissions compared to 1990 levels and at least a $27 \%$ share of renewable energy consumption. ${ }^{194}$ The road to these ambitious energy sustainability goals does not always produce the most efficient market outcome and on the contrary, faces various economic and market barriers for the production of energy from renewable sources. ${ }^{195}$ This is why State aid is an appropriate instrument to achieve the Union objectives and to remove the existing market irregularities: it must be ensured that the State intervention corrects the market failures and does not distort the market. The Member States can achieve their mentioned targets thanks to this reflection of the environmental protection objective in the State aid rules.

\section{Environmental tax reductions}

In the majority of cases, State aid is granted as direct financial contributions, be it in the form of a grant, loans with a long-running payback period, interest-free loans, guarantees or others. Indirect aid is, on the other hand, not the result of an expense for the State, but rather comprises a loss or non-realisation of revenue, ${ }^{196}$ with favourable taxation conditions to some undertakings being an obvious example. Taxation aid in the form of reductions, reliefs and benefits are subject to State aid control in the same way as direct financial support. ${ }^{197}$

The purpose of imposing environmental taxes is building up or developing the environmentallyfriendliness of undertakings by increasing the costs of environmentally harmful conduct: the rationale of such taxes is to protect the environment by penalising polluting activities. ${ }^{198}$ Environmental taxes discourage such

\footnotetext{
190 Bram Delvaux, 'The EC State Aid Regime Regarding Renewables: Opportunities and Pitfalls', (2003) 12(4) European Energy and Environmental Law Review 103, 112

${ }^{191}$ Erika Szyszczak, 'Commission Communication on Guidelines on State Aid for Environmental Protection and Energy 2014-2020' [2014] < https:/ssrn.com/abstract=2464290 > accessed 11 May 2019

${ }_{192}$ Dir 2009/28/EC of the European Parliament and of the Council of 23 April 2009 on the promotion of the use of energy from renewable sources and amending and subsequently repealing Directives 2001/77/EC and 2003/30/EC [2009] OJ L140/16, Article 3

193 Commission, 'Europe 2020' (n 178) 9

${ }^{194}$ Commission, 'From 2020 to 2030' (n 181) 5

${ }^{195}$ Corinna Klessmann and others, 'Status and Perspectives of Renewable Energy Policy and Deployment in the European Union - What is Needed to Reach the 2020 Targets?', (2011) 39(12) Energy Policy 7637, 7651

${ }^{196}$ Commission, 'Notice on the notion of State aid' (n 126) para 115

${ }^{197}$ Calster and Reins (n 74) 171

198 Phedon Nicolaides and Maria Kleis, 'Critical Analysis of Environmental Tax Reductions and Generation Adequacy Provisions in the EEAG 2014-2020’ (2014) 13(4) European State Aid Law Quarterly 636, 641
} 
behaviour, target certain activities, goods or services so that the environmental costs may be included in their price, and producers and consumers are oriented towards activities which better respect the environment and thus, increase the overall level of environmental protection. Reductions, or exemptions from, such taxes (Article 44 GBER, Section 3.7 EEAG) may also play a role to encourage more respectful behaviour towards the environment. For example, the introduction by the UK of a full tax exemption for natural gas in Northern Ireland for five years was held by the Commission permissible because otherwise, further barriers to the development of the Northern Irish gas industry would be created. ${ }^{199}$ An exemption from the Dutch energy tax on natural gas for ceramic producers was, however, held to be unnecessary and disproportionate. ${ }^{200}$ When adopting measures reducing the level of environmental taxes for some categories of undertakings, the main goal of discouraging environmentally harmful behaviour should not be impaired.

Aid schemes are based on a reduction of the applicable tax rate, on the payment of a fixed amount of compensation or both. Reductions should be necessary, appropriate, based on objective, transparent and nondiscriminatory criteria and bring an incentive effect to the beneficiary undertakings to contribute to improving the environmental protection. They are considered as contributing to an increased level of environmental protection if the granting State grants the reductions to undertakings most affected by a higher tax. To determine this, the Commission assesses the proportionality of the measures and how the new look taxation contributes to environmental protection.

The irony of aid in the form of reductions in, or exemptions from, environmental taxes is that such reductions and exemptions relieve the undertakings from bearing certain environmental costs that they should normally incur and thus, from more environmentally-friendly behaviour. If such taxes are designed to protect the environment from harmful activities, how can exemptions or reductions from those taxes contribute to improving environmental conditions? ${ }^{201}$ But this paradox loses much of its effect if the aid is genuinely capable of encouraging certain undertakings or sectors to carry out their practices in a more environmentally sensitive manner, even more than they do when not exempted partially or wholly from such taxes. Although reductions in, or exemptions from, environmental taxes may eliminate the level playing field for all undertakings, they may still be necessary to remove the market failures where some undertakings suffer from a material competitive disadvantage: treating such undertakings more favourably may ultimately result in a higher level of environmental protection. Considering these, it can be said that the State aid policy reflects the due account of environmental considerations in the context of reductions in, and exemptions from, environmental taxes.

One thing the Guidelines miss with regard to environmental tax reductions is the precision of some terms (feasibility, substantial increase in production costs, important sales reductions, significant competitive disadvantage, unsustainable financing of renewable support, etc.) used to justify the compatibility of such

\footnotetext{
${ }^{199}$ Commission, 'Notice on the notion of State aid' (n 148) para 386

${ }^{200}$ Commission Decision (C(2009) 9972) 2010/402 on an aid measure which the Netherlands proposes to implement, granting ceramic producers exemption from an environmental tax C 5/09 (ex N 210/08) [2009]

${ }^{201}$ Phedon Nicolaides, 'In Search of Economically Rational Environmental State Aid: The Case of Exemption from Environmental Taxes' (2014) 10(1) European Competition Journal 155, 156
} 
reductions with the internal market, which may result with a non-necessary and disproportionate grant of environmental aid. ${ }^{202}$

\section{Aid for remediation of contaminated sites}

The EU environmental policy objective of preserving, protecting and improving the quality of the environment, the goals of sustainable development and the environmental principles - principles of prevention, proximity and 'polluter pays' - all pursue preventing or eliminating the consequences of environmental pollution in the EU. In the field of environmental State aid, pollution is a polluter's direct or indirect damage to the environment or creation of conditions liable for such damage to physical surroundings or natural resources. Guided by the said objectives and principles, the EU law considers the investment aid to repair environmental damage by remediating contaminated sites (Article 45 GBER) compatible with the internal market if other compatibility conditions are met.

This does not, however, mean that those committed the damage are not responsible to remove it and that damage should be eliminated through State aid - the PPP, according to which the costs of dealing with pollution should be internalised and borne by those who cause it, requires the polluters liable for the environmental damage to finance the remediation as a rule. Environmental State aid policy often sees a confrontation between State aid measures and the PPP. The chief approach of the standard EU source with respect to the PPP and the allocation of environmental costs is that environmental protection should not in principle depend on policies which rely on grants of aid, and place the burden of combating pollution on society. ${ }^{203}$ A grant to an undertaking polluting a site to clean up the pollution amounts to incompatible aid where the clean-up costs are not subsequently recovered from it. For example, Austrian funding for the clean-up operation was held to be State aid because the costs were not recovered from the owner. ${ }^{204}$ Aid for remediation of contaminated sites is allowed to be granted to the person responsible for the remediation or decontamination work only if the person liable for the damage is not identified or cannot be made to bear the costs. The aid must effectively lead to the repair of the environmental damage, including damage to the quality of the soil, surface water or groundwater.

The question of PPP comes into the centre of attention constantly when granting this type of aid unlike the other types covered in the preceding subsections. Exempting the aid for remediation of contaminated sites may, in general terms, seem like a positive step towards a proper reflection of environmental considerations in the State aid rules, however, it must be ensured that the application of this exemption does not relieve the polluters from their responsibilities under the EU and national laws. Moreover, although only undertakings not liable for the environmental damage caused in the site may receive aid, still there are remaining problems:

\footnotetext{
202 Phedon Nicolaides and Maria Kleis, 'Critical Analysis of Environmental Tax Reductions and Generation Adequacy Provisions in the EEAG 2014-2020' (2014) 13(4) European State Aid Law Quarterly 636

${ }^{203}$ Council Recommendation 75/436 regarding cost allocation and action by public authorities on environmental matters [1975] Annex, point 2

${ }^{204}$ Commission Decision (C(1998) 4195) on the measure planned by Austria for the clean-up of the Kiener Deponie Bachmanning landfill [1998]
} 
European legislation on contaminated sites is not well-developed and some Member States have different rules on parties' responsibility. Besides, the legal responsibility of the property owner, who has not caused pollution, is not included in the Guidelines. ${ }^{205}$

\section{Aid for waste management}

Aid for waste management (Article 47 GBER, Section 3.5 EEAG) can be a valuable tool for the EU objectives of combating climate change and sustainable development. The exemption applies to the investment aid for operations by which (i) waste materials are reprocessed into materials whether for the original or other purposes (recycling) and (ii) non-waste materials are used again for the same designated purpose they previously had (re-utilisation) and not for other recovery operations. The aid may be granted to undertakings for recovering materials generated by other undertakings, and not by the aid beneficiary. It may only be awarded if the recycled and re-used materials would otherwise be disposed of or be treated in a less environmentally friendly manner in the absence of aid.

The requirements for adopting aid measures for waste management is laid down by taking into account the EU target of preventing, reusing and recycling waste, ${ }^{206}$ the obligation on the Member States to establish waste management plans ${ }^{207}$ and the PPP, according to which undertakings should bear the costs to manage the waste they generate. Aid for the management of waste can contribute to a higher level of environmental protection if it does not circumvent the principle of the waste hierarchy ${ }^{208}$ and negatively impacts the normal functioning of the secondary materials market. The exemption of aid 'encourages' Member States not to hesitate to grant aid to private undertakings if it improves the waste management system in that country. However, as in the previous type of aid, the requirements of the PPP should not be undermined to ensure that the aid does not relieve the polluters from their burden under the Union law or from a burden which is a normal company cost. Here the term 'polluter' covers those who directly or indirectly damages the environment or creates conditions leading to such damage.

\section{Aid for energy infrastructure}

Aid to energy infrastructure (Article 48 GBER, Section 3.8 EEAG) enhances the functioning of the internal energy market and strengthens the integration of different energy sources and energy supply. State aid may be granted to cover some parts of the investment needed where market failures in terms of positive externalities and coordination problems emerge as a result of market operators' inability to deliver the energy infrastructure projects, in particular the cross-border and regional ones.

\footnotetext{
${ }^{205}$ Joachim Sanden, The EEAG 2014-2020 and the Remediation of Contaminated Sites, (2014) 13(4) European State Aid Law Quarterly 650, 661 ${ }^{206}$ Union Environment Action Programme to 2020 (n 92). See, eg, Annex: The 7th Environment Action Programme to 2020 - 'Living well, within the limits of our planet', para 39

${ }^{207}$ Dir 2008/98/EC of the European Parliament and of the Council on waste and repealing certain Directives [2008] OJ L312/3, art 28

208 ibid art 4(1)
} 
Investment aid for the construction or upgrade of energy infrastructure is a block-exempted aid category. The infrastructure, that is the physical equipment or facility which is located within the EU or linking the Union to a third country, must be subject to full tariff and access regulation according to internal energy market legislation. It should be noted, however, that the aid for investments in electricity and gas storage projects, and oil infrastructure is not exempted under this category.

To be authorised by the Commission, aid for energy infrastructure should contribute to an objective of common interest and lack undue distortive effects. Normally, compulsory user tariffs are the appropriate means of financing energy infrastructure, but State aid may also be considered appropriate to fund an energy infrastructure if it is among Projects of Common Interest ${ }^{209}$ and where financing through such tariffs is insufficient. To identify the need for State intervention in the field of energy infrastructure, the Commission carries out a case-by-case assessment by taking into account the seriousness of the situation the concerned market failure leads to and the necessity of the contribution the project makes to the EU energy supply security. The amount of aid to energy infrastructure should be minimum to reach the objective pursued.

The 2011 Commission evaluation showed that until 2020 an investment of about EUR 200 billion is needed for energy infrastructures of European significance to maintain the supply security and facilitate the market integration of renewable energy. ${ }^{210}$ Aid for energy infrastructure is beneficial to the internal market as it strengthens system stability, integration of different energy sources and energy supply in underdeveloped networks. While this category of aid can address coordination problems and positive externalities, it needs to be justified by referring to market failures that cannot be removed by other means such as by compulsory user tariffs. ${ }^{211}$

\subsubsection{Compatibility Assessment under the TFEU rules}

If environmental aid measures do not fall within the scope of the Regulation or the Guidelines, they still can be declared by the Commission compatible with the internal market through direct application of the Treaty rules. The Commission can examine and, if appropriate, approve aid that exceeds the thresholds set out in the EEAG unless it has an explicit position against the aid in question in the Guidelines. ${ }^{212}$

Article 107(3)(c) TFEU is the most used basis for granting horizontal, sectoral and regional aid benefiting particular activities or areas. According to the provision, aid to facilitate the development of certain economic activities or certain economic areas may be considered to be compatible with the internal market by the Commission. For aid to be authorised directly under Article 107(3)(c) TFEU, it must not adversely affect intra-

\footnotetext{
${ }^{209}$ Regulation (EU) No 347/2013 of the European Parliament and of the Council on guidelines for trans-European energy infrastructure and repealing Decision No 1364/2006/EC and amending Regulations (EC) No 713/2009, (EC) No 714/2009 and (EC) No 715/2009 [2013] OJ L349/28, Annex VII

${ }^{210}$ Energy infrastructure investment needs and financing requirements (Commission Staff Working Paper) SEC(2011) 755 final, 2

211 Bacon (n 54) 244

${ }^{212}$ Case T-375/03 Fachvereinigung Mineralfaserindustrie v [2007] EU:T:2007:293, para 143
} 
Union trading conditions to an extent contrary to the common interest. ${ }^{213}$ One of the recent examples of the application of this basis is the compensation of the German government for the closure of lignite power plants. ${ }^{214}$ After establishing that State aid existed, in the meaning of Article 107(1) TFEU, the Commission examined the measures in question and concluded that they are compatible with the internal market in accordance with Article 107(3)(c) TFEU. The Commission cleared the aid measure adopted by the UK to establish and fund the Green Investment Bank to provide complementary financing to green projects in the UK and thus, addressing market failures in funding such projects after examining it in the light of Article 107(3)(c) TFEU. ${ }^{215}$ In another case, a budget increase for German aid scheme to support the acquisition of electric buses for public transport was approved directly under Article 107(3)(c) TFEU as the EEAG were ruled not applicable. ${ }^{216}$

On the other hand, Article 107(3)(b) TFEU can also 'come to the rescue' when the Member States intend to grant environmental State aid. According to the provision, aid to remedy a serious disturbance in the economy or to promote the execution of an important project of common European interest may be considered to be compatible with the internal market by the Commission. The Commission has published a communication to indicate the criteria for the analysis of the compatibility of State aid for important projects of common European interest. ${ }^{217}$ Environmental State aid may be granted under the 'remedy a serious disturbance in the economy' limb as well. For example, the Commission did not raise objections against the French scheme supporting green businesses during the 2008 financial crisis after assessing the measure under the second limb of Article 107(3)(b) TFEU. ${ }^{218}$

The Commission may also authorise aid for a service of general economic interest pursuant to Article 106(2) TFEU, according to which, undertakings carrying out the services of general economic interest are subject to the competition rules where such rules do not obstruct the performance of those services. State compensation for a service of general economic interest does not amount to State aid if the following four cumulative conditions, which are known as the Altmark criteria, are met: (i) the existence of actual and clearly defined public service obligations to discharge, (ii) the establishment of parameters based on which the compensation is calculated in advance in an objective and transparent manner, (iii) avoidance of compensation exceeding what is necessary to cover the costs incurred in the discharge of public service obligations, and (iv) the determination of the level of compensation on the basis of cost analysis which a typical, well-run and adequately provided undertaking would have incurred in discharging those obligations. ${ }^{219}$ If a State measure does not meet these conditions, then it can be examined and authorised by the Commission under Article 106(2) TFEU.

\footnotetext{
${ }^{213}$ See, eg, Case C-310/85 Deufil v Commission [1987] EU:C:1987:96, paras 16, 18

${ }^{214}$ Commission Decision (C(2016) 3124) State Aid SA.42536 - Germany: Closure of German lignite-fired power plants [2016] paras 52-87

${ }^{215}$ Commission Decision (C(2012) 7133 final) SA.33984 (2012/N) - UK: Green Investment Bank [2012] paras 110-156

${ }^{216}$ Commission Decision (C(2020) 585 final) SA.55977 (2019/N) - Germany: Third budget increase for scheme to support acquisition of electric buses for urban public transport [2020]

${ }^{217}$ Commission, 'Criteria for the analysis of the compatibility with the internal market of State aid to promote the execution of important projects of common European interest' (Communication)

${ }^{218}$ Commission Decision (C(2009) 695 final) N 11/2009 - France: Temporary subsidized loan scheme for companies manufacturing green products [2009] paras 33-36

219 Case C-280/00 Altmark Trans and Regierungspräsidium Magdeburg [2003] EU:C:2003:415, paras 88-93
} 
The Commission has authorised, by applying Article 106(2) TFEU, several State aid measures, often for the acquisition of land for nature conservation. In a coal power case, the Commission examined the government support for indigenous coal power plants in Spain.220 The intervention in question met all but the fourth condition of the Altmark criteria as Spain did not provide the required costs analysis which a typical business would have incurred in discharging the considered service. Despite this, the Commission still went on to find the transaction compatible with the internal market as compensation for the security of supply obligations, pursuant to Article 106(2) TFEU. In another case, although the Maltese government put the aid for the construction and operation of a gas and power project into effect without the relevant authorisation in breach of Article 108(3) TFEU, the Commission still found the aid compatible with the internal market under Article 106(2) TFEU. 221

Thanks to the GBER and the EEAG, the Member States do not have to rely on the Treaty rules for the authorisation by the Commission of the environmental aid they plan to grant to private undertakings. However, the fact that the Commission allows some State aid measures, which fall into the scope of neither instrument, directly under Articles 107(3) and 106(2) TFEU clearly extends the scope of authorisation recognised for certain types of environmental State aid. This, in turn, allows the Member States to apply for the Commission authorisation when they intend to address certain environmental challenges through aid to private undertakings, even if that aid is not covered by the Regulation or the Guidelines. As a result, the integration and reflection of environmental protection requirements in the State aid policy reach another level.

${ }^{220}$ Commission Decision (C(2010) 4499) State aid No N 178/2010 - Spain: Public service compensation linked to a preferential dispatch mechanism for indigenous coal power plants [2010]. See, in particular, paras 108, 148, 163

${ }^{221}$ Commission Decision (C(2017) 2 final) SA.45779 (2016/NN) - Malta: Delimara Gas and Power Energy Project [2017] 


\section{CONCLUSION}

Today, Europe faces environmental issues of "unprecedented scale and urgency". ${ }^{222}$ Although the EU is one of the top-performing parts of the world in environmental matters, the recent stats show that European countries face serious environmental challenges nowadays. Environmental policy has long been at the centre of attention in the EU even though the Union still experiences massive environmental problems today. Although this policy area is responsible for the protection of the environment in the EU, a high level of environmental protection could not be reached without cooperating with other policy areas. With this in mind, the Treaty of Amsterdam of 1997 established the requirement of integrating environmental protection into all EU policies as a Treaty rule. The State aid policy of the EU is not an exception - integration of environmental protection into the State aid control is a duty before the policymakers. Article 107(1) TFEU lays down that aid in the form of an advantage granted by the Member States to selected businesses, which affects the intra-Union trade, is prohibited. This prohibition encompasses aid granted for environmental purposes as well. Besides, according to the PPP, environmental damage should be removed at the expense of those who caused that damage and not by the wider society. Despite these, large amounts of public resources are still used to prevent and remedy damage to the environment. This ultimately means that it is not really always the polluter that pays, but the resources of the general public are often involved in overcoming the environmental damages or threats emerged thanks to the activities of private companies.

So, on the one hand, State aid control is essential to maintain a high level of competition in the internal market, while on the other hand, the EU aims to have a high level of environmental protection, which must also be integrated into the State aid policy. This thesis project studied how environmental protection and its requirements are integrated into the State aid policy when these two legitimate interests of the EU intersect. Discussions on whether environmental considerations can or should be taken into account in the State aid policy are irrelevant: it is not disputed that they can and should be. ${ }^{223}$ The research problem was, instead, how these considerations are reflected in the State aid policy.

It was necessary to understand the fundamentals of EU law and general legal framework that applies to the situation before going deep into the research question. First, the objectives of the Union, which must be complied by all Union policies and activities, were briefly looked into. The problem in this study was examined in the light of two objectives of the Union - the internal market and the environmental protection. Establishing an internal market is the most emblematic project and an inherent objective of the EU. According to Article 26 TFEU, the internal market is an area without internal frontiers where the free movement of goods, persons, services and capital is ensured under the provisions of the EU Treaties. The internal market is designed to increase economic wealth and economies of scale, and improve the efficiency of the allocation of resources by allowing the factors of production to freely move to the areas where they are most valued. It is also the driving force of the European economic integration, as previously separate economies of the Member States become integrated within a single EU-wide market. Another objective of the Union is achieving a high level of protection

\footnotetext{
${ }^{222}$ European Environmental Agency, 'Impacts, Vulnerability and Risks' (European Environmental Agency, last modified 10 February 2020) $<$ https://www.eea.europa.eu/themes/climate-change-adaptation/impacts-vulnerability-and-risks> accessed 24 February 2020

${ }^{223}$ Kingston, Greening EU Competition Law and Policy (n 55) 380
} 
and improvement of the quality of the environment, which entails both reactive ("protection") and proactive ("improvement") approach to environmental policy.

Next, the general principles of EU law and their place in the EU State aid and environmental policies were briefly analysed. General principles of EU law unify the law, fill the gaps, and provide for weight and legitimacy to the EU legal order as a whole. They are indispensable for uniform interpretation of the Union law by the Court. Fundamental rights, which originate either from Convention for the Protection of Human Rights and Fundamental Freedoms or constitutional traditions of Member States, are now incorporated into a single and Treaty-equivalent document. Article 37 CFREU enshrines the fundamental right to environmental protection, while other fundamental rights and freedoms are also applied in State aid cases. The principle of equal treatment or non-discrimination and the principle of legal certainty, are also relevant to State aid control and environmental protection.

Finally, the division of power in the Union was shortly explored in relation to State aid and environmental matters. Establishing competition rules necessary for the functioning of the internal market, which include State aid rules as well, is an area where the EU has exclusive competences to develop the policy, legislate and adopt binding acts alone. Moreover, Article 108 TFEU recognises the exclusive competence of the Commission in assessing the compatibility of State aid with the internal market, subject only to the Court supervision. On the other hand, the area of environment hosts shared competences between the EU and the Member States. This is a potential source for conflicts of interests pursued, on one hand, by the EU to keep the competition undistorted and, on the other, by the Member States to address their environmental concerns.

The study also explored the general legal framework covering the two policy areas at hand and the integration requirement. First, the State aid policy of the EU was studied. State aid control plays the role of an important instrument for establishing the internal market and pursuing a high level of competition in the EU. According to Article 107(1) TFEU, aid granted by a Member State or through State resources which distorts or threatens to distort competition by favouring certain undertakings or the production of certain goods is prohibited if it affects trade between Member States. Pursuant to Article 107(2) and (3) TFEU, a measure can still be compatible with the internal market in some cases even if it is found to be State aid.

Next, the focus turned to the environment policy of the EU. The basis of the legal framework of the EU environmental policy is Article 191 TFEU. Article 191(1) TFEU lays down the objectives of the EU environmental policy, which include (i) preserving, protecting and improving the quality of the environment, (ii) protecting human health, (iii) prudent and rational utilisation of natural resources and (iv) promoting measures at the international level to deal with regional or worldwide environmental problems, and in particular combating climate change. Article 191(2) TFEU specifies the principles which the environmental policy of the Union bases on: the principles of precaution, prevention, proximity and the PPP. According to Article 191(3) TFEU, the EU must prepare its environmental policy by taking account of certain criteria: scientific and technical data, environmental conditions in the various regions of the EU, benefits and costs of action or lack of action, and the economic and social development of the Union and its regions. 
Finally, the environmental integration requirement was shortly touched on. Article 11 TFEU states that environmental protection requirements must be integrated into the Union's policies and activities, in particular with a view to promoting sustainable development.

The research question is answered in the next chapter. First, the environmental State aid policy of the EU, which reveals the conditions, areas and thresholds for granting State aid for the protection of the environment, was briefly described. In the field of State aid control, the environmental considerations are taken into account, and reflected, through the environmental State aid policy. The policy intends to ensure that the State aid control is coherent with the requirements of the EU environmental policy. Next, the existence of environmental State aid is investigated. Existence of environmental State aid cannot be proved if an environmental support measure does not meet all conditions of the notion of State aid, which are the presence of economic advantage, State involvement, selectivity, and threat to distort competition and to affect trade between the Member States. Finally, the compatibility of environmental State aid with the internal market was deeply explored. To take the due account of, and reflect, the environmental protection requirements in the State aid rules, the Commission has adopted the GBER and the EEAG, which, respectively, exempts certain categories of environmental aid from the notification obligation and stipulate the compatibility conditions of environmental aid measures, which do not fall into the scope of the Regulation, with the internal market. Moreover, if environmental aid measures do not fall within the scope of the Regulation or the Guidelines, they still can be declared by the Commission compatible with the internal market through direct application of the Treaty rules.

Although the block exemptions and the environmental State aid guidelines go back in history, the 2005 State aid action plan remodelled the Commission's State aid control practice. It resulted in a more comprehensive and complete environmental and energy aid guidelines compared to their predecessors. It also led to the addition of several conditions relating to aid granted for environmental protection by the Commission in the block exemption regulation.

One drawback of the environmental State aid is that it may lead to an impediment of the market's ability to reward the most efficient undertakings while encouraging the least efficient ones to improve. This situation can undermine the level playing field principle as on some occasions the environmental aid beneficiaries would be granted an unfair advantage over more efficient or innovative competitors. In turn, this kind of State intervention may restrain and slow down the innovative improvements in the long term. On the other hand, environmental State aid may also, directly or indirectly, increase the recipient's market power and ultimately, distort the Union competition. Such distortion is not limited only to the product markets and may also extend to the location choices when undertakings compete across the Union: State support may lead to displacement of activities or investments from one region into another without any net environmental impact.

Nevertheless, environmental State aid can play a role of an important tool to remove market failures, strengthen private undertakings, help them to become more environmentally friendly businesses and overcome environmental challenges in the EU. Member States may need to restrict competition in certain markets to better attain the desired environmental objectives. It is especially inevitable and desirable in the time of facing climate 
issues no matter how one wishes the economy to stay liberal, and away from distortions and State interventions. On the other hand, as mentioned, the Union pursues its interest to control State aid in order to respect the objective of establishing the internal market and the PPP. The EU environmental State aid policy should, therefore, be looked at against this background of conflicting interests.

Integrating environmental considerations in State aid control does not simply mean all aid with an environmental motive should be allowed to be granted. This would conflict with the PPP as well as lead to distortion of competition: such treatment can lead to a situation where the polluter would not pay for the damage caused, thereby distorting competition and upsetting the polluter-pays principle. To prevent this outcome the Commission uses a more balanced approach in the Regulation and the Guidelines: it balances the environmental benefit against negative effects of the aid measure in terms of distortions of competition. ${ }^{224}$ The adoption of the GBER and the EEAG by the Commission is a vital step for building a sensitive framework to balance these conflicting interests. In that sense, I find the position of the Commission, who is in charge of State aid control in the EU and known for its firm positioning in State aid cases from time to time, quite generous. This approach allows the Member States to grant certain kinds of environmental and energy aid to the businesses with or without notification to the Commission. This is a very sensible way of integrating environmental protection requirements into the State aid rules. However, this integration is not limited to the State aid rules but also shows itself in the Commission's individual decisions in State aid cases as well. A higher level of integration, though, would come with a Treaty amendment to make the purpose of the environmental protection a direct Treaty exemption for State aid measures.

EU State aid control should support the environmental transformation of the economy to bring it into line with the Union's energy and climate change objectives. ${ }^{225}$ The need for environmental State aid will continue to exist because of the growing and unforeseen challenges that the EU environmental policy is going to meet in the near future. With the emergence of new environmental issues and development of the existing best practice, State aid will have some role to play in continuing the transition towards environmental sustainability.

\footnotetext{
${ }^{224}$ Nowag (n 93) 198-199

${ }^{225}$ Ezcurra, 'EU State Aid and Energy Policies' (n 113) 673
} 


\section{BIBLIOGRAPHY}

\section{Books}

1. Bacon K, European Union Law of State Aid (3 $3^{\text {rd }}$ edn, OUP 2017)

2. Calster G and Reins L, EU Environmental Law (Edward Elgar 2017)

3. Craig P and Burca G, EU Law: Text, Cases, and Materials (5 ${ }^{\text {th }}$ edn, OUP 2011)

4. Dhondt N, Integration of Environmental Protection into Other EC Policies: Legal Theory and Practice (Europa Law 2003)

5. Jans J and Vedder H, European Environmental Law (4 $4^{\text {th }}$ edn, Europa Law 2012)

6. Kingston S, Greening EU Competition Law and Policy (CUP 2011) 'Integrating Environmental Protection and EU Competition Law: Why Competition Isn't Special' (2010) 16(6) European Law Journal 780

7. Kramer L, EC Environmental Law (6 ${ }^{\text {th }}$ edn, Sweet \& Maxwell 2007)

8. Langlet D and Mahmoudi S, EU Environmental Law and Policy (OUP 2016)

9. Nowag J, Environmental Integration in Competition and Free-Movement Laws (OUP 2016)

10. Sadeleer N, EU Environmental Law and the Internal Market (OUP 2014)

- - Environmental Principles: From Political Slogans to Legal Rules (OUP 2002)

11. Swann D, The Economics of the Common Market (7th edn, Penguin 1992)

12. Tridimas T, The General Principles of EU Law (2 ${ }^{\text {nd }}$ edn, OUP 2006)

\section{Contributions to Edited Books}

1. Bobek M, 'The Effects of EU Law in the National Legal Systems' in Catherine Barnard and Steve Peers (eds), European Union Law (2nd edn, OUP 2017)

2. Costamagna F, 'The Internal Market and the Welfare State: Anything New after Lisbon?' in Martin Trybus and Luca Rubini (eds), The Treaty of Lisbon and the Future of European Law and Policy (Edward Elgar 2012)

3. Craig P, 'The Evolution of the Single Market' in Catherine Barnard and Joanne Scott (eds), The Law of the Single European Market: Unpacking the Premises (Hart 2002)

4. Cuyvers A, 'General Principles of EU Law' in Emmanuel Ugirashebuja and others (eds), East African Community Law: Institutional, Substantive and Comparative EU Aspects (Brill 2017)

5. Drexl J, 'Competition Law as Part of the European Constitution' in Jurgen Bast and Armin von Bogdandy (eds), Principles of European Constitutional Law (2 ${ }^{\text {nd }}$ edn, Hart 2009)

6. Ezcurra M, 'Energy Taxation and State Aid Law' in Isabelle Richelle, Wolfgang Schön and Edoardo Traversa (eds), State Aid Law and Business Taxation (Max Planck Institute Studies in Tax Law and Public Finance, vol 6, Springer 2016)

7. Gerber D, 'The Future of Article 82: Dissecting the Conflict' in Claus-Dieter Ehlermann and Mel Marquis (eds), European Competition Law Annual 2007: A Reformed Approach to Article 82 EC (Hart 2008) 
8. Heimler A, 'State Aid Control: Recent Developments and Some Remaining Challenges' in Pier Luigi Parcu, Giorgio Monti, Marco Botta (eds), EU State Aid Law: Emerging Trends at the National and EU Level (Edward Elgar 2020)

9. Hession M and Macrory R, 'The Legal Duty of Environmental Integration: Commitment and Obligation or Enforceable Right' in Timothy O'Riordan and Heather Voisey (eds), The Transition to Sustainability: The politics of Agenda 21 in Europe (Earthscan 1998)

10. Mahmoudi S, 'Integration of Environmental Considerations into Transport' in Richard Macrory (ed), Reflections on 30 Years of EU Environmental Law (Europa Law 2006)

11. McGowan F, 'Competition Policy: The Limits of the European Regulatory State' in Helen Wallace and William Wallace (eds) Policy-Making in the European Union (4 $4^{\text {th }}$ edn, OUP 2000)

12. Rasmussen M, 'From Costa v ENEL to the Treaties of Rome: A Brief History of a Legal Revolution', in Miguel Maduro and Loic Azoulai (eds), The Past and Future of EU Law: The Classics of EU Law Revisited on the 50 th Anniversary of the Rome Treaty (Hart 2010)

13. Schwalbe U, 'European State Aid Control - State Aid Action Plan' in Jurgen Basedow and Wolfgang Wurmnest (eds), Structure and Effects in EU Competition Law: Studies on Exclusionary Conduct and State Aid (Kluwer Law International 2011)

14. Winter G, 'The Legal Nature of Environmental Principles in International, EC and German Law' in Richard Macrory (ed), Principles of European Environmental Law (Europa Law 2004)

\section{Articles}

1. Alblas E, 'Conflicting Goals and Mixed Rationales: A Closer Look at the Objectives of EU Environmental Law in Light of the Anthropocene' (2018) 27(2) Review of European Comparative \& International Environmental Law 141

2. Andersen B, 'Revision of Environmental Guidelines', (2008) 17(1) European Energy and Environmental Law Review 23

3. Arena A, 'From an Unpaid Electricity Bill to the Primacy of EU Law: Gian Galeazzo Stendardi and the Making of Costa v. ENEL' (2019) 30(3) European Journal of International Law 1017

4. Blauberger M, 'From Negative to Positive Integration? European State Aid Control through Soft and Hard Law', Discussion Paper 08/4, (2008) Max Planck Institute for the Study of Societies

5. Callaerts R, 'State Aid for the Production of Electricity from Renewable Energy Resources', (2015) 24(1) European Energy and Environmental Law Review 17

6. Daniela J and others, 'EURO-CORDEX: New High-Resolution Climate Change Projections for European Impact Research' (2014) 14(2) Regional Environmental Change 563

7. Delvaux B, 'The EC State Aid Regime Regarding Renewables: Opportunities and Pitfalls', (2003) 12(4) European Energy and Environmental Law Review 103

8. Englisch J, 'Equality under State Aid Rules and VAT' (2019) 8 World Journal of VAT/GST Law 17

9. Ezcurra M, 'EU State Aid and Energy Policies as an Instrument of Environmental Protection: Current Stage and New Trends' (2014) 13(4) European State Aid Law Quarterly 665 
10. Flam K, 'EU Environmental State Aid Policy: Wide Implications, Narrow Participation?' (2009) 19 Environmental Policy and Governance 336

11. Kingston S, 'Integrating Environmental Protection and EU Competition Law: Why Competition Isn't Special' (2010) 16(6) European Law Journal 780

12. Klessmann C and others, 'Status and Perspectives of Renewable Energy Policy and Deployment in the European Union - What is Needed to Reach the 2020 Targets?', (2011) 39(12) Energy Policy 7637

13. Lenaerts K, 'The Autonomy of European Union Law' (2018) 4 Diritto dell'Unione Europea 617

14. Lenaerts K and Gutierrez-Fons J, 'To Say What the Law of the EU Is: Methods of Interpretation and the European Court of Justice' (2014) 20(2) Columbia Journal of European Law 3

15. Misonne D, 'The Importance of Setting a Target: The EU Ambition of a High Level of Protection' (2015) 4(1) Transnational Environmental Law 11

16. Nicolaides P, 'In Search of Economically Rational Environmental State Aid: The Case of Exemption from Environmental Taxes' (2014) 10(1) European Competition Journal 155

17. Nicolaides P and Kleis M, 'Critical Analysis of Environmental Tax Reductions and Generation Adequacy Provisions in the EEAG 2014-2020' (2014) 13(4) European State Aid Law Quarterly 636

18. Rzotkiewicz M, 'The General Principles of EU Law and Their Role in the Review of State Aid Put into Effect by Member States', (2013) 3 European State Aid Law Quarterly 464

19. Sanden J, The EEAG 2014-2020 and the Remediation of Contaminated Sites, (2014) 13(4) European State Aid Law Quarterly 650

20. Schumacher T, 'The Environmental Integration Clause in Article 6 of the EU Treaty: Prioritising Environmental Protection' (2001) 3(1) Environmental Law Review 29

21. Sciskalova M and Munster M, 'Definition and Characteristics of State Aid', (2014) 110 Procedia - Social and Behavioral Sciences 223

22. Weiler J, 'The Transformation of Europe', (1991) 100(8) The Yale Law Journal 2403

23. Wessmaier M, 'The Integration of Environmental Protection as General Rule for Interpreting Law' (2001) 38(1) CMLR 159

\section{Documents of the European Commission}

1. Commission Staff Working Paper (SEC(2011) 755 final) Energy infrastructure investment needs and financing requirements

2. Communication $(\mathrm{COM}(2000) 1$ final $)$ on the precautionary principle

3. Communication (COM(2010) 2020 final) Europe 2020: A strategy for smart, sustainable and inclusive growth

4. Communication (COM(2011) 21 final) A resource-efficient Europe - Flagship initiative under the Europe 2020 Strategy

5. Communication (COM(2011) 571 final) Roadmap to a Resource Efficient Europe

6. Communication (COM(2014) 15 final) A policy framework for climate and energy in the period from 2020 to 2030

7. Communication (D/290869) relating to the methodology for analysing State aid linked to stranded costs 
8. Communication (SWD(2012) 130 final) Guidelines on certain State aid measures in the context of the greenhouse gas emission allowance trading scheme post-2012

9. Communication - Criteria for the analysis of the compatibility with the internal market of State aid to promote the execution of important projects of common European interest

10. Communication - Guidelines on State aid for environmental protection and energy 2014-2020

11. Consultation document (COM(2005) 107 final) State Aid Action Plan - Less and Better Targeted State Aid: A Roadmap for State Aid Reform 2005-2009

12. Notice (C/2016/2946) on the notion of State aid as referred to in Article 107(1) of the Treaty on the Functioning of the European Union

\section{Reports}

1. European Commission, XXVIII Report on Competition Policy (Office of Official Publications of the European Communities 1998)

- - XXXI Report on Competition Policy (Office of Official Publications of the European Communities 2001)

2. European Environmental Agency, European Waters: Assessment of Status and Pressures 2018 (Publications Office of the European Union 2018)

- - The European Environment - State and Outlook 2015: Synthesis Report (Publications Office of the European Union 2015)

3. European Union Committee, Brexit: Competition and State Aid (HL 2017-19, 67)

4. Wendling Z and others, 2018 Environmental Performance Index (Yale Center for Environmental Law \& Policy 2018)

\section{Webpages}

1. European Commission, 'State Aid Scoreboard 2018' (European Commission, last updated 24 January 2019) $<$ https://ec.europa.eu/competition/state aid/scoreboard/index en.html\#what > accessed 26 February 2020

2. European Environmental Agency, 'Air Pollution' (European Environmental Agency, last modified 09 October 2017) <https://www.eea.europa.eu/themes/air/intro> accessed 18 February 2020

3. European Environmental Agency, 'Biodiversity - Ecosystems' (European Environmental Agency) $<$ https://www.eea.europa.eu/themes/biodiversity> accessed 18 February 2020

4. European Environmental Agency, 'Contamination from Local Sources' (European Environmental Agency, last modified 21 November 2019) <https://www.eea.europa.eu/themes/soil/soil-threats> accessed 24 February 2020

5. European Environmental Agency, 'Impacts, Vulnerability and Risks' (European Environmental Agency, last modified 10 February 2020)

$<$ https://www.eea.europa.eu/themes/climate-change-adaptation/impacts-vulnerability-and-risks $>$ accessed 24 February 2020 
6. Shirley A, 'Which Are the World's Most Environmentally Friendly Countries?' (World Economic Forum, 20 May 2016) <https://www.weforum.org/agenda/2016/05/which-are-the-worlds-most-environmentallyfriendly-countries/> accessed 5 June 2020

7. Szyszczak E, ‘Commission Communication on Guidelines on State Aid for Environmental Protection and Energy 2014-2020' [2014] < https:/ssrn.com/abstract=2464290 $>$ accessed 11 May 2019

\section{Other Secondary Sources}

1. Kingston S, 'The Role of Environmental Protection in EC Competition Law and Policy' (PhD Thesis, Leiden University 2009)

2. Kroes N, 'Competition Policy: Achievements in 2006; Work Programme in 2007; Priorities for 2008' (2007) European Parliament Economic and Monetary Affairs Committee, Speech/07/425 (26 June 2007)

3. The European Consultative Forum on the Environment and Sustainable Development, Statement on Environmental Integration (1998) 